University of Nebraska - Lincoln

DigitalCommons@University of Nebraska - Lincoln

1992

\title{
First- and Second-Order Patterns of Stress in the Lithosphere: The World Stress Map Project
}

Mary Lou Zoback

U.S. Geological Survey, marylouz@stanford.edu

Follow this and additional works at: https://digitalcommons.unl.edu/usgsstaffpub

Part of the Earth Sciences Commons

Zoback, Mary Lou, "First- and Second-Order Patterns of Stress in the Lithosphere: The World Stress Map Project" (1992). USGS Staff -- Published Research. 461.

https://digitalcommons.unl.edu/usgsstaffpub/461

This Article is brought to you for free and open access by the US Geological Survey at DigitalCommons@University of Nebraska - Lincoln. It has been accepted for inclusion in USGS Staff -- Published Research by an authorized administrator of DigitalCommons@University of Nebraska - Lincoln. 


\title{
First- and Second-Order Patterns of Stress in the Lithosphere: The World Stress Map Project
}

\author{
MARY LOU ZOBACK \\ U.S. Geological Survey, Menlo Park, California
}

\begin{abstract}
To date, more than 7300 in situ stress orientations have been compiled as part of the World Stress Map project. Of these, over 4400 are considered reliable tectonic stress indicators, recording horizontal stress orientations to within $< \pm 25^{\circ}$. Remarkably good correlation is observed between stress orientations deduced from in situ stress measurements and geologic observations made in the upper 1-2 km, well bore breakouts extending to $4-5 \mathrm{~km}$ depth and earthquake focal mechanisms to depths of $\sim 20 \mathrm{~km}$. Regionally uniform stress orientations and relative magnitudes permit definition of broad-scale regional stress patterns often extending 20-200 times the approximately $20-25 \mathrm{~km}$ thickness of the upper brittle lithosphere. The "first-order" midplate stress fields are believed to be largely the result of compressional forces applied at plate boundaries, primarily ridge push and continental collision. The orientation of the intraplate stress field is thus largely controlled by the geometry of the plate boundaries. There is no evidence of large lateral stress gradients (as evidenced by lateral variations in stress regime) which would be expected across large plates if simple resistive or driving basal drag tractions (parallel or antiparallel to absolute motion) controlled the intraplate stress field. Intraplate areas of active extension are generally associated with regions of high topography: western U.S. Cordillera, high Andes, Tibetan plateau, western Indian Ocean plateau. Buoyancy stresses related to crustal thickening and/or lithospheric thinning in these regions dominate the intraplate compressional stress field due to plate-driving forces. These buoyancy forces are just one of several categories of "second-order" stresses, or local perturbations, that can be identified once the first-order stress patterns are recognized. These second-order stress fields can often be associated with specific geologic or tectonic features, for example, lithospheric flexure, lateral strength contrasts, as well as the lateral density contrasts which give rise to buoyancy forces. These second-order stress patterns typically have wavelengths ranging from 5 to $10+$ times the thickness of the brittle upper lithosphere. A two-dimensional analysis of the amount of rotation of regional horizontal stress orientations due to a superimposed local stress constrains the ratio of the magnitude of the horizontal regional stress differences to the local uniaxial stress. For a detectable rotation of $15^{\circ}$, the local horizontal uniaxial stress must be at least twice the magnitude of the regional horizontal stress differences. Examples of local rotations of $S_{H \max }$ orientations include a $75^{\circ}-85^{\circ}$ rotation on the northeastern Canadian continental shelf possibly related to margin-normal extension derived from sediment-loading flexural stresses, a $50^{\circ}-60^{\circ}$ rotation within the East African rift relative to western Africa due to extensional buoyancy forces caused by lithospheric thinning, and an approximately $90^{\circ}$ rotation along the northern margin of the Paleozoic Amazonas rift in central Brazil. In this final example, this rotation is hypothesized as being due to deviatoric compression oriented normal to the rift axis resulting from local lithospheric support of a dense mass in the lower crust beneath the rift ("rift pillow"). Estimates of the magnitudes of first-order (plate boundary force-derived) regional stress differences computed from modeling the source of observed local stress rotations magnitudes can be compared with regional stress differences based on the frictional strength of the crust (i.e., "Byerlee's law") assuming hydrostatic pore pressure. The examples given here are too few to provide a definitive evaluation of the direct applicability of Byerlee's law to the upper brittle part of the lithosphere, particularly in view of uncertainties such as pore pressure and relative magnitude of the intermediate principal stresses. Nonetheless, the observed rotations all indicate that the magnitude of the local horizontal uniaxial stresses must be 1-2.5+ times the magnitude of the regional first-order horizontal stress differences and suggest that careful evaluation of such local rotations may be a powerful technique for constraining the in situ magnitude stress differences in the upper, brittle part of the lithosphere.
\end{abstract}

\section{INTRODUCTION}

The World Stress Map (WSM) project is a global cooperative effort to compile and interpret data on the orientation and relative magnitudes of the contemporary in situ tectonic stress field in the Earth's lithosphere. The project was initiated in 1986 under the auspices of the International Lithosphere Program and currently involves over 30 scientists from more than 18 different countries (Table 1) who have been directly responsible for systematic compilation of the available stress data in the geographic regions indicated. To date, over 7300 data points have been compiled in a

This paper is not subject to U.S. copyright. Published in 1992 by the American Geophysical Union.

Paper number 92JB00132. digital data base. The focus of this effort has been to characterize the intraplate or midplate stress field (i.e., the state of stress within the plates) rather than the details and complexities within and along the plate boundaries, where the overall kinematics and deformation are generally well known.

Preliminary results of the WSM global stress compilation were reported by Zoback et al. [1989] and corroborated findings of numerous regional compilations of in situ stress and focal mechanism data and indicated that broad regions within the interior of many plates are characterized by uniformally oriented $\left( \pm 15^{\circ}\right)$ horizontal stresses. These relatively uniform midplate stress orientations are documented in continental regions over distances up to $5000 \mathrm{~km}$. Correlations between regional intraplate stress orientations and 


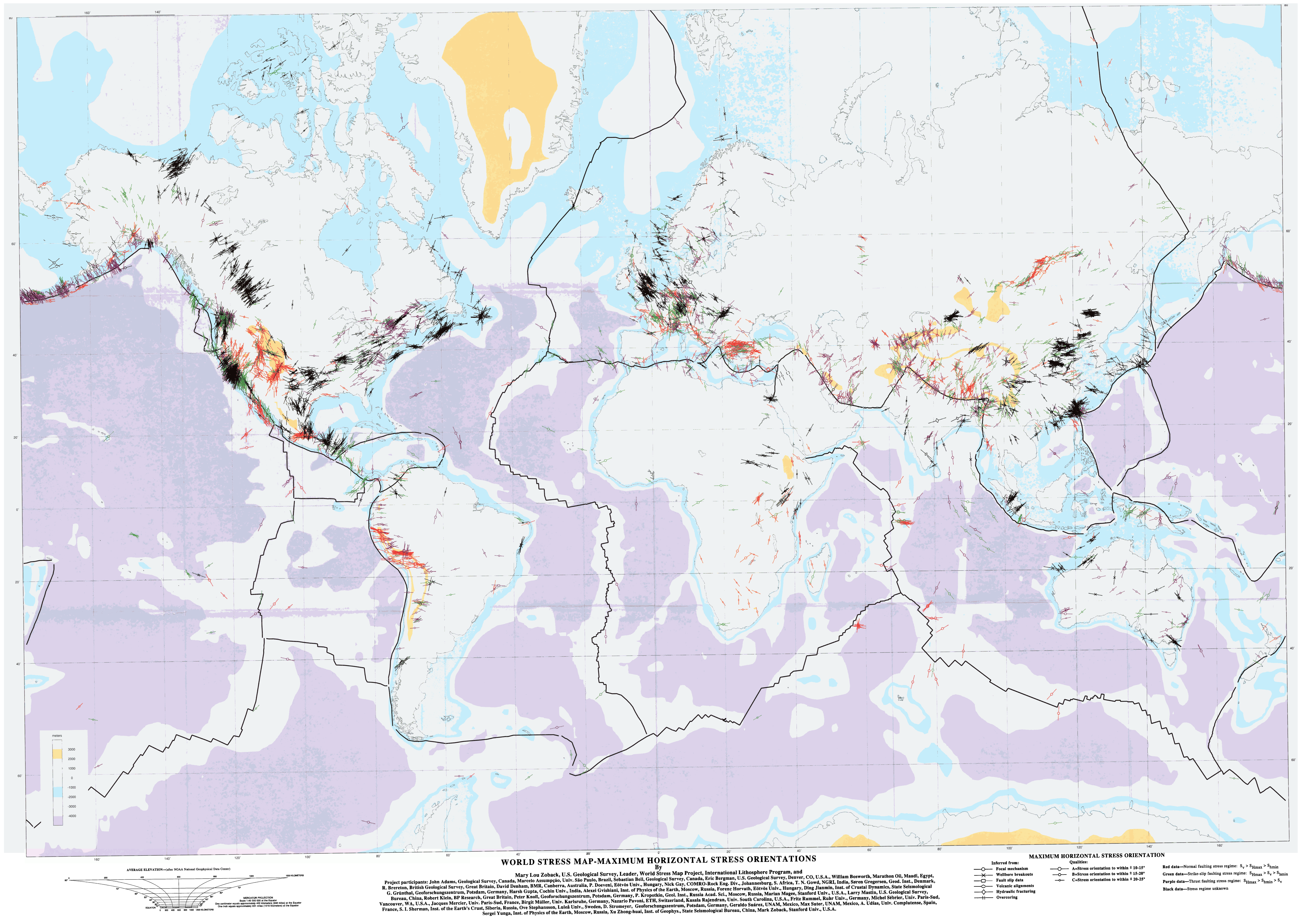


TABLE 1. World Stress Map Project Participants

\begin{tabular}{|c|c|}
\hline Region Covered & Participant \\
\hline North America & $\begin{array}{l}\text { John Adams, Geological Survey of Canada } \\
\text { Sebastian Bell, Geological Survey of Canada } \\
\text { Marian Magee, U.S. Geological Survey, Menlo Park, California } \\
\text { Mary Lou Zoback, U.S. Geological Survey, Menlo Park, } \\
\text { California } \\
\text { Mark Zoback, Stanford University, California }\end{array}$ \\
\hline Central America & $\begin{array}{l}\text { Max Suter, Universidad Nacional Autónoma México } \\
\text { Geraldo Suarez, Universidad Nacional Autónoma México }\end{array}$ \\
\hline South America & $\begin{array}{l}\text { Marcelo Assumpço, Universidade de São Paulo, Brazil } \\
\text { Jacques Mercier, Université Paris-Sud, France } \\
\text { Michel Sebrier, Université Paris-Sud, France }\end{array}$ \\
\hline Australia & David Denham, Bureau of Mineral Resources, Canberra, Australia \\
\hline China & $\begin{array}{l}\text { Ding Jianmin, Institute of Crustal Dynamics, State Seismological } \\
\text { Bureau, China } \\
\text { Xu Zhonghuai, Institute of Geophysics, State Seismological } \\
\text { Bureau, China }\end{array}$ \\
\hline India & $\begin{array}{l}\text { T. N. Gowd, National Geophysical Research Institute, India } \\
\text { Harsh Gupta, Cochin University, India } \\
\text { Kusala Rajendran, University of South Carolina }\end{array}$ \\
\hline Western Europe & $\begin{array}{l}\text { R. Brereton, British Geological Survey, Great Britain } \\
\text { Robert Klein, BP Research, Great Britain } \\
\text { Birgit Müller, Universität Karlsruhe, Germany } \\
\text { Larry Mastin, Universität Karlsruhe, Germany } \\
\text { Fritz Rummel, Ruhr Universität, Germany } \\
\text { Nazario Pavoni, Eidgenössische Technische Hochschule Zurich, } \\
\text { Switerzerland } \\
\text { A. Udias, Universidad Complutense, Spain }\end{array}$ \\
\hline Fennoscandia & $\begin{array}{l}\text { Soren Gregersen, Geodetic Institute, Denmark } \\
\text { Ove Stephansson, Lulea University, Sweden }\end{array}$ \\
\hline Central Europe & $\begin{array}{l}\text { P. Doeveny, Eötvös University, Hungary } \\
\text { G. Grunthal, Central Institute of Physics of the Earth, Potsdam, } \\
\text { Germany } \\
\text { Forenc Horvath, Eötvös University, Hungary } \\
\text { Peter Knoll, Central Institute of Physics of the Earth, Potsdam, } \\
\text { Germany } \\
\text { D. Stromeyer, Central Institute of Physics of the Earth, Potsdam, } \\
\text { Germany }\end{array}$ \\
\hline $\begin{array}{l}\text { Eastern Europe and Central } \\
\text { and Western Asia }\end{array}$ & $\begin{array}{l}\text { Alexei Gvishiani, Institute of Physics of the Earth, Moscow, } \\
\text { Russia } \\
\text { P. Kropotkin, Geological Institute, Russian Academy of Sciences, } \\
\text { Moscow } \\
\text { S. I. Sherman, Institute of the Earth's Crust, Siberia Russia } \\
\text { Sergei Yunga, Institute of Physics of the Earth, Moscow, Russia }\end{array}$ \\
\hline Africa & $\begin{array}{l}\text { William Bosworth, Marathon Oil, Maadi, Egypt } \\
\text { Nick Gay, COMRO, Rock Engineering Division, Johannesburg, } \\
\text { South Africa }\end{array}$ \\
\hline Oceanic Intraplate & Eric Bergman, U.S. Geological Survey, Denver, Colorado \\
\hline
\end{tabular}

both absolute and relative plate motions were first noted by Sbar and Sykes [1973], Yang and Aggarwal [1981], Gough [1984], and Zoback and Zoback [1980, 1981, 1991] in North America. These correlations are discussed on a global scale by Zoback et al. [1989] (see also Assumpcao [this issue], Richardson [this issue], and Müller et al. [this issue]) and suggest that the forces driving and resisting plate motion are the primary source of most of these very broad scale stress fields.

Once "regional" stress fields are defined, it is possible to identify local anomalies or perturbations to this regional field. Local variations in stress orientation and relative magnitude exist at a variety of scales. These variations may be due to a variety of forces acting on the lithosphere: buoyancy and flexure forces on the broad wavelength end (100-5000+ km, depending on the size of the load) to thermal, topographic, and other site specific effects on the very short wavelength end $(<1 \mathrm{~km})$.

The purpose of this paper is multifold. First, it serves as an introduction to the other papers in this special section, presenting the current status of the global compilation effort including a summary description of stress indicators and the philosophy behind the quality ranking scheme. By agreement, the methodology and stress indicators used in the 
World Stress Map (WSM) project are discussed here and not given in detail in each of the individual papers. Second, this paper describes the general characteristics of the data set and provides an overview of both first- and second-order broad-scale stress patterns identified in the data. These patterns are described in terms of the constraints that they place on the relative importance and magnitude of forces acting on and within the lithosphere and also on their relationship to structure of the lithosphere. Finally, this paper develops a methodology to utilize rotations of the maximum horizontal stress due to local geologic and tectonic structures to constrain regional horizontal stress magnitude differences. This analysis serves as an example of how stress orientation data compiled in the WSM may be exploited in the future to constrain in situ stress magnitudes at seismogenic depths.

The accompanying papers in this special section focus on three main subjects: interpretation of the stress data contained in the data base; the relationship of the stress field to the tectonics and structure of individual regions; and utilization of the stress data to constrain geodynamic problems, including the relative and absolute magnitudes of plate tectonic forces and the forces responsible for intraplate deformation.

\section{World Stress Map Data Base}

The current version of the global stress data base is shown on a page size map in Figure 1 and on a large size color map in Plate 1 (separate folded map). On both maps the maximum horizontal stress $\left(S_{H \max }\right.$ ) orientations derived from all the different stress measurement techniques described below are plotted on a background of average topography. All of the stress data are compiled in a digital data base which is available on floppy diskettes through World Data Center A at the National Geophysical Data Center in Boulder, Colorado. The data format is fairly complex because we have tried to standardize and tabulate the maximum amount of information from a wide variety of data types. We have tried to retain all information pertinent to stress orientation (number of determinations, mean, standard deviation, and depth range); however, by necessity, our data base is not complete for all types of data. In particular, detailed stress magnitude information (e.g., individual stress determinations in a single well) is not compiled; only the values at maximum depth or a gradient determination are given. However, in cases where there is a clear change in stress orientation with depth, both the shallow information and deep stress orientation information are included in the data base; in general, the deeper information is given a higher-quality ranking.

It is important to note that the WSM data base complements a number of regional data compilations which in many cases are more complete. The reader is referred to these regional data bases for additional information: Canadian crustal stress data base (all data types) [Adams, 1987], Fennoscandian Rock Stress Database (overcoring and hydrofracture measurements) [Stephansson et al., 1987], Harvard Centroid Moment Tensor catalogs (focal mechanisms) [Dziewonski and Woodhouse, 1983] (now published with the U.S. National Earthquake Information Center (NEIC) Preliminary Determination of Epicenters Catalog), European Hydrofac Stress Database (maintained at Ruhr University of Bochum, Germany (F. Rummel, written communication,
1991), and the breakout catalog for Great Britain [Brereton and Evans, 1987].

\section{Stress Indicators and Quality Ranking}

Six types of geological and geophysical data in four different categories are used to infer tectonic stress information: earthquake focal mechanisms, well bore breakouts, in situ stress measurements (hydraulic fracturing and overcoring), and young geologic data including fault slip and volcanic alignments. The assumptions, difficulties, and uncertainties of inferring in situ stress orientations from these different indicators have been discussed in detail previously [Zoback and Zoback, 1980; Zoback et al., 1989; Zoback and Zoback, 1991]. It should be stated at the outset that the age of "young" geologic data is generally Quaternary. In some regions of active tectonism, recent changes in stress orientation and style of faulting have been proposed in PlioceneQuaternary time on the basis of paleostress analysis primarily utilizing fault slip data (e.g., see Mercier et al. [this issue] for recent stress changes in the Andes and Mercier et al. [1987a] for recent changes in the Aegean region). In these areas we have only compiled the youngest episode of deformation. However, in some tectonically stable midplate regions such as the eastern United States we have extended the time window back to include evidence of post-Miocene faulting.

A quality ranking scheme was developed by Zoback and Zoback [1989] to assess how reliably an individual data point records the tectonic stress field and also to permit comparison of orientations inferred from very different types of information. A detailed discussion of the rationale and criteria for assigning quality to data derived from different types of indicators is given by Zoback and Zoback [1991]. The reader is referred to Zoback and Zoback [1991] for much of the basic theory and limitations associated with the application of the various stress measurement techniques as this information is not repeated below.

Five qualities are used in ranking the data, $A>B>C>D$, and $\mathrm{E}$. The quality ranking scheme is given in Table 2 and is identical to that of Zoback and Zoback [1989] and Zoback and Zoback [1991] with the addition of the E quality category described below indicating analyzed data that contain no useful stress orientation information. As indicated in Table 2, the ranking criteria include accuracy of the measurements, the number of determinations, the depth interval and volume of rock sampled, and the general reliability of the particular method as a tectonic (as opposed to local) stress indicator (based primarily on the rock volume sampled). For stress directions inferred from earthquake focal mechanisms a magnitude cutoff is also used in the ranking, with the higher-quality ranking assigned to the larger earthquakes.

The available evidence from the orientation of fault planes observed in the field as well as inferred from earthquake focal mechanisms, attitude of dikes, and deep in situ stress measurements suggests that the principal stress field in the lithosphere lies in approximately horizontal and vertical planes [e.g., Anderson, 1951; McGarr and Gay, 1978; Zoback and Zoback, 1980]. We assume then that the orientation of the in situ stress tensor can thus be approximated from the maximum horizontal stress ( $S_{H \max }$ ) azimuth. The A quality data described in Table 2 are believed to record the 


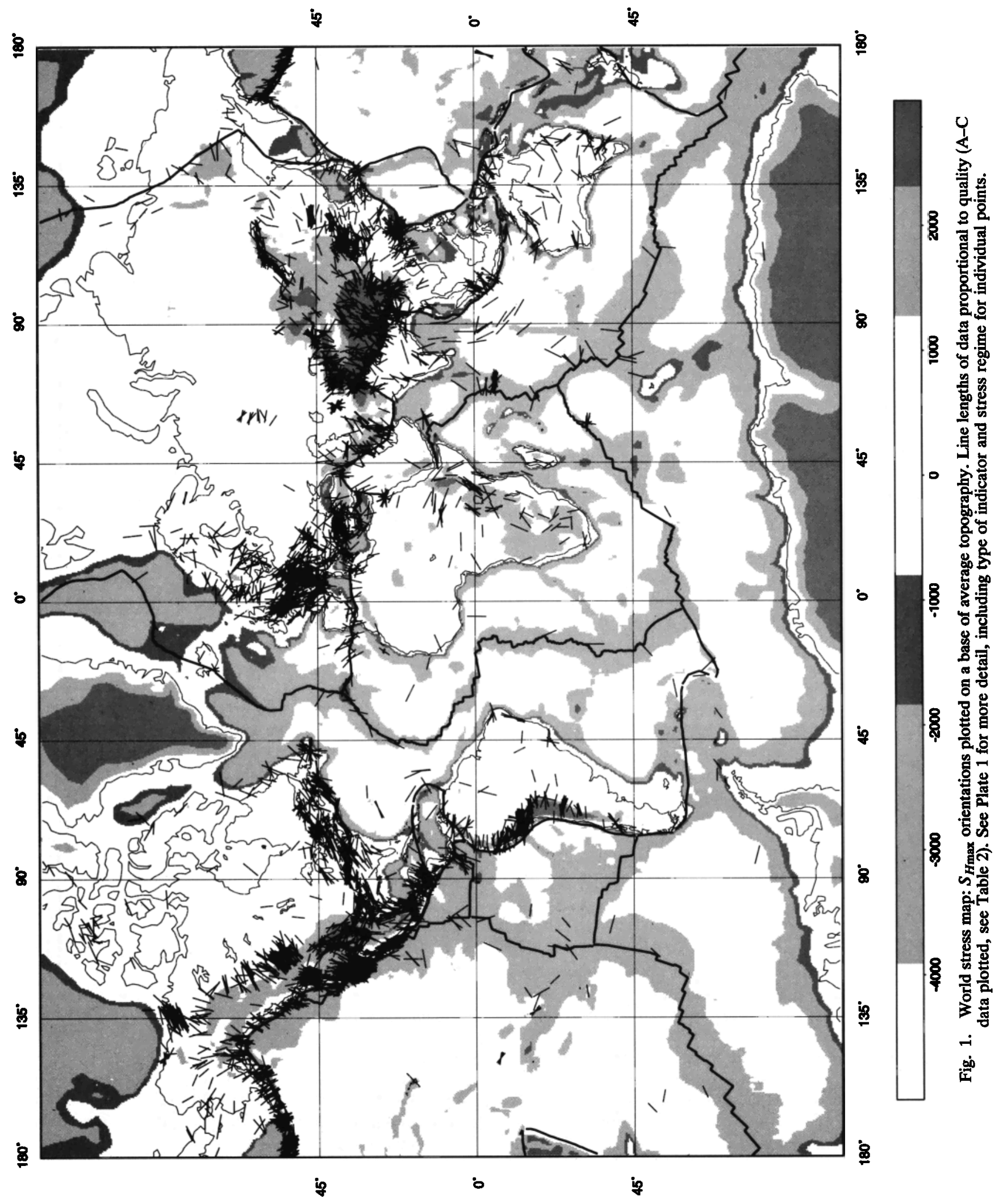


TABLE 2. Quality Ranking System for Stress Orientations

\begin{tabular}{|c|c|c|c|c|}
\hline A & B & $\mathrm{C}$ & D & $\mathrm{E}$ \\
\hline $\begin{array}{l}\text { Average } P \text { axis or } \\
\text { formal inversion of } \\
\text { four or more single- } \\
\text { event solutions in } \\
\text { close geographic } \\
\text { proximity (at least one } \\
\text { event } M \geq 4.0 \text {, other } \\
\text { events } M \geq 3.0 \text { ) }\end{array}$ & $\begin{array}{l}\text { Well-constrained single- } \\
\text { event solution }(M \geq \\
4.5) \text { or average of two } \\
\text { well-constrained } \\
\text { single-event solutions } \\
(M \geq 3.5) \text { determined } \\
\text { from first motions and } \\
\text { other methods (e.g., } \\
\text { moment tensor } \\
\text { waveform modeling or } \\
\text { inversion) }\end{array}$ & $\begin{array}{l}\text { Focal Mechanism }(F M) \\
\text { Single-event solution } \\
\text { (constrained by first } \\
\text { motions only, often } \\
\text { based on author's } \\
\text { quality assignment) } \\
(M \geq 2.5 \text { ) } \\
\text { Average of several } \\
\text { well-constrained } \\
\text { composites ( } M \\
>2.0 \text { ) }\end{array}$ & $\begin{array}{l}\text { Single composite } \\
\text { solution } \\
\text { Poorly constrained } \\
\text { single-event solution } \\
\text { Single-event solution for } \\
M<2.5 \text { event }\end{array}$ & $\begin{array}{l}\text { Large historic event with } \\
\text { no reliable focal } \\
\text { mechanism } \\
\text { Event with } P, T, B \text { axes } \\
\text { all plunging } 25^{\circ}-40^{\circ} \\
\text { Event with } P \text { and } T \text { axes } \\
\text { both plunging } 40^{\circ}-50^{\circ}\end{array}$ \\
\hline $\begin{array}{l}\text { Ten or more distinct } \\
\text { breakout zones in a } \\
\text { single well with s.d. } \\
\leq 12^{\circ} \text { and/or combined } \\
\text { length }>300 \mathrm{~m} \\
\text { Average of breakouts in } \\
\text { two or more wells in } \\
\text { close geographic } \\
\text { proximity with } \\
\text { combined length }>300 \\
\text { m and s.d. } \leq 12^{\circ}\end{array}$ & $\begin{array}{l}\text { At least six distinct } \\
\text { breakout zones in a } \\
\text { single well with s.d. } \\
\leq 20^{\circ} \text { and } / \text { or combined } \\
\text { length }>100 \mathrm{~m}\end{array}$ & $\begin{array}{l}\text { Well Bore Breakout }(I S-B O) \\
\text { At least four distinct } \\
\text { breakouts with s.d. } \\
<25^{\circ} \text { and } / \text { or } \\
\text { combined length } \\
>30 \mathrm{~m}\end{array}$ & $\begin{array}{l}\text { Less than four } \\
\text { consistently oriented } \\
\text { breakouts or }<30 \mathrm{~m} \\
\text { combined length in a } \\
\text { single well } \\
\text { Breakouts in a single } \\
\text { well with s.d. } \geq 25^{\circ}\end{array}$ & $\begin{array}{l}\text { Wells in which no } \\
\text { reliable breakouts } \\
\text { detected } \\
\text { Extreme scatter of } \\
\text { orientations, no } \\
\text { significant mean } \\
\text { determined (s.d. }>\mathbf{4 0}^{\circ} \text { ) }\end{array}$ \\
\hline $\begin{array}{l}\text { Four or more hydrofrac } \\
\text { orientations in single } \\
\text { well with s.d. } \leq 12^{\circ} \text {, } \\
\text { depth }>300 \mathrm{~m} \\
\text { Average of hydrofrac } \\
\text { orientations for two or } \\
\text { more wells in close } \\
\text { geographic proximity, } \\
\text { s.d. } \leq 12^{\circ}\end{array}$ & $\begin{array}{l}\text { Three or more hydrofrac } \\
\text { orientations in a single } \\
\text { well with s.d. }<20^{\circ} \\
\text { Hydrofrac orientations } \\
\text { in a single well with } \\
12^{\circ}<\text { s.d. } \leq 25^{\circ}\end{array}$ & $\begin{array}{l}\text { Hydraulic Fracture }(I S-H F) \\
\text { Hydrofrac orientations } \\
\text { in a single well with } \\
20^{\circ}<\text { s.d. }<25^{\circ} ; \\
\text { distinct hydrofrac } \\
\text { orientaiton change } \\
\text { with depth, deepest } \\
\text { measurements } \\
\text { assumed valid } \\
\text { One or two hydrofrac } \\
\text { orientations in a } \\
\text { single well }\end{array}$ & $\begin{array}{l}\text { Single hydrofrac } \\
\text { measurement at }<100 \\
\text { m depth }\end{array}$ & $\begin{array}{l}\text { Wells in which only } \\
\text { stress magnitudes } \\
\text { measured, no } \\
\text { information on } \\
\text { orientations }\end{array}$ \\
\hline \multicolumn{5}{|c|}{$\begin{array}{l}\text { Petal Centerline Fracture }(I S-P O) \\
\text { Mean orientation of } \\
\text { fractures in a single } \\
\text { well with s.d. }<20^{\circ}\end{array}$} \\
\hline $\begin{array}{l}\text { Average of consistent } \\
\left(\mathrm{s.d} \leq 12^{\circ}\right) \\
\text { measurements in two } \\
\text { or more boreholes } \\
\text { extending more than } \\
\text { two excavation radii } \\
\text { from the excavation } \\
\text { wall and far from any } \\
\text { known local } \\
\text { disturbances, depth } \\
>300 \mathrm{~m}\end{array}$ & $\begin{array}{l}\text { Multiple consistent (s.d. } \\
<20^{\circ} \text { ) measurements } \\
\text { in one or more } \\
\text { boreholes extending } \\
\text { more than two } \\
\text { excavation radii from } \\
\text { excavation well, depth } \\
>100 \mathrm{~m}\end{array}$ & $\begin{array}{l}\text { Overcore }(I S-O C) \\
\text { Average of multiple } \\
\text { measurements made } \\
\text { near surface (depth } \\
>5-10 \mathrm{~m}) \text { at two or } \\
\text { more localities in } \\
\text { dose proximity with } \\
\text { s.d. } \leq 25^{\circ} \\
\text { Multiple measurements } \\
\text { at depth }>100 \mathrm{~m} \\
\text { with } 20^{\circ}<\text { s.d. }<25^{\circ}\end{array}$ & $\begin{array}{l}\text { All near-surface } \\
\text { measurements with } \\
\text { s.d. }>15^{\circ} \text {, depth }<5 \mathrm{~m} \\
\text { All single measurements } \\
\text { at depth } \\
\text { Multiple measurements } \\
\text { at depth with s.d. } \\
>25^{\circ}\end{array}$ & $\begin{array}{l}\text { Multiple measurements } \\
\text { at a single site or } \\
\text { locality with no } \\
\text { significant mean (s.d. } \\
>40^{\circ} \text { ) }\end{array}$ \\
\hline $\begin{array}{l}\text { Inversion of fault-slip } \\
\text { data for best fitting } \\
\text { mean deviatoric stress } \\
\text { tensor using } \\
\text { Quaternary age faults }\end{array}$ & $\begin{array}{l}\text { Slip direction on fault } \\
\text { plane, based on mean } \\
\text { fault attitude and } \\
\text { multiple observations } \\
\text { of the slip vector; } \\
\text { inferred maximum } \\
\text { stress at } 30^{\circ} \text { to fault }\end{array}$ & $\begin{array}{l}\text { Fault Slip (G-FS) } \\
\text { Attitude of fault and } \\
\text { primary sense of slip } \\
\text { known, no actual } \\
\text { slip vector }\end{array}$ & $\begin{array}{l}\text { Offset core holes } \\
\text { Quarry popups } \\
\text { Postglacial surface fault } \\
\text { offsets }\end{array}$ & Not complied \\
\hline $\begin{array}{l}\text { Five or more Quaternary } \\
\text { vent alignments or } \\
\text { "parallel" dikes with } \\
\text { s.d. }<12^{\circ}\end{array}$ & $\begin{array}{l}\text { Three or more } \\
\text { Quaternary vent } \\
\text { alignments or } \\
\text { "parallel" dikes with } \\
\text { s.d. }<20^{\circ}\end{array}$ & $\begin{array}{l}\text { canic Vent Alignment* }(G-V \\
\text { Single well-exposed } \\
\text { Quatemary dike } \\
\text { Single alignment with } \\
\text { at least five vents }\end{array}$ & $\begin{array}{l}\text { Volcanic alignment } \\
\text { inferred from less than } \\
\text { five vents }\end{array}$ & Not compiled \\
\hline
\end{tabular}

s.d., standard deviation.

*Volcanic alignments must be based, in general, on five or more vents or cinder cones. Dikes must not be intruding a regional joint set. 
orientation of the horizontal tectonic stress field to within $\pm 10^{\circ}-15^{\circ}$, the $\mathrm{B}$ quality data to within $\pm 15^{\circ}-20^{\circ}$, and the $\mathrm{C}$ quality data to within $\pm 25^{\circ}$. D quality data described in Table 2 are considered to yield questionable tectonic stress orientations for several reasons: widely scattered or sometimes bimodal orientations observed at a single site (breakout, hydraulic fracture, or overcoring measurements with a standard deviation (s. d.) $>25^{\circ}$ ); the small volume of rock sampled (e.g., small ( $m<2.5$ ) earthquakes or less than four breakouts); or very shallow near-surface measurements potentially perturbed by topographic or even thermal stresses (overcoring) or near-surface fracturing (hydrofractures). For this reason, only orientations from the "reliable" A-C data are plotted on Plate 1 and on most of the maps included in this special section. In some cases, orientations from the D quality data agree well with the surrounding information; however, in many other cases they contribute a great deal of scatter to the regional picture. Therefore we have adopted rather conservative criteria for our compilation, preferring to possibly downgrade some "good" data rather than trying to plot every piece of information collected in a region.

In a few cases, data are upgraded in quality by the investigator who collected them for specific circumstances not adequately accounted for in the general quality ranking table. For example, the mean stress direction inferred from breakouts in two or more wells in close proximity may be given a higher quality than would be strictly indicated by the total breakout length; the rationale being that multiple, consistent orientations in different depth intervals in adjacent wells are a significant observation. In nearly all cases the reason for the quality upgrade is noted in the comments accompanying the data in the data base.

Data in the fifth quality category, " $E$ ", have been analyzed and found to yield no reliable information regarding principal stress orientations. Examples of this type of information are given in Table 2. There are at least two good reasons for including these data in the data base. Sometimes extreme scatter and the lack of consistent stress orientations in a given well or at a given locality may be a very valuable piece of information regarding the local state of stress; for example, the stress field may be locally horizontally isotropic and the effects due to small-scale perturbations of the stress field due to presence of fracturing or interacting faults may dominate. Furthermore, the $\mathrm{E}$ category is useful for record-keeping purposes; for example, if data from a particular hole, region, or earthquake have been examined once, it is helpful to know that that examination yielded no useable information. Generally, statements in comments accompanying each entry in the data base indicate the problem, for example, "well-log quality was too poor to be read or interpreted." In general, there are many gaps in E entries; since they yield no useful stress orientation information, they have not been systematically compiled.

As mentioned above, the limitations associated with the various types of stress indicators and the evaluation criteria for assigning quality were developed previously [Zoback and Zoback, 1991] and are only summarized below. The distribution of the data by type of indicator is shown in Figure $2 a$. Note that here and throughout the paper statistics are done on only the "reliable" (A-C) quality data.

Earthquake focal mechanisms. As shown in Figure $2 a$, the focal mechanism data are by far the most abundant in the data set $(54 \%)$ and provide valuable information on the relative magnitudes of the principal stresses. However, most focal mechanism data are B or C quality data (see Table 2) since $P$ and $T$ axes for an individual earthquake may differ significantly from the actual stress orientations producing the slip [e.g., McKenzie , 1969]. For that reason, no singleevent focal mechanism is given an A quality, regardless of how well-constrained that mechanism might be or the magnitude of the event. Mean best fitting deviatoric stress tensors or geometrically determined mean directions of $\boldsymbol{P}$ and $T$ axes for focal mechanisms from a single source region are assigned an $\mathrm{A}$ quality since these mean directions or inversion results approximate quite well the regional stress field as represented by independent data [e.g., Michael, 1987; Zoback, 1989].

Qualities are based in part on how well the mechanism is constrained (generally determined by investigator constructing the focal mechanism) and also based on earthquake magnitude as an indication of the volume of rock sampled and the amount of strain released. Very small magnitude events $(m<2.5)$ are assigned a D quality. Even if the focal mechanisms for these events are reliable, these earthquakes may represent deformation due to the complex interaction of active faults rather than deformation in response to the regional stress field. This is often the case for aftershocks; hence only main shock mechanisms are compiled.

Well-constrained mechanisms (B quality data) are generally available for large magnitude earthquakes, particularly for those events with $M>4.5-5.0$ which are recorded teleseismically and some waveform modeling or inversion technique has been used in addition to first motions to constrain the nodal planes. However, in areas of a dense seismic network and detailed crustal structure and velocity information (e.g., California), well-constrained focal mechanisms may be available for smaller-magnitude events. Mechanisms for moderate earthquakes (4.0-6.0) based only on local first motions from a sparse regional network are given a $\mathrm{C}$ quality.

The centroid moment tensor (CMT) inversions done by the Harvard group [Dziewonski and Woodhouse, 1983] (and now published in the NEIC Preliminary Determination of Epicenters catalog, as mentioned previously) are generally also assigned a $\mathrm{C}$ quality if there is no additional study of the event. This lower quality, despite the fact that magnitudes are typically $\geq 5.0$, is due to the relatively poor resolution of the CMT inversion for the vertical dip-slip components of faulting in shallow focus events [Sipkin, 1986; Anderson, 1988]. Assumpcao [this issue] conducted an analysis of CMT solutions in South America in which he checked the solution for consistency with $\boldsymbol{P}$ wave polarities at World-Wide Standard Seismograph Network (WWSSN) stations and some high-gain Brazilian stations and found that 18 of $20 \mathrm{CMT}$ solutions he investigated were compatible with the regional polarity data and two solutions were not.

As indicated in Table 2, composite focal mechanisms are generally given a $\mathrm{D}$ quality. Often these mechanisms are done for local very diffuse seismicity or for aftershocks (which as mentioned above are generally not included). However, if a rock volume is deforming in response to a uniform regional stress tensor, careful objective (grid search) composites of a large number of events may yield reliable stress information. $X u$ et al. [this issue] demonstrated this with a series of tests creating composites of randomly 


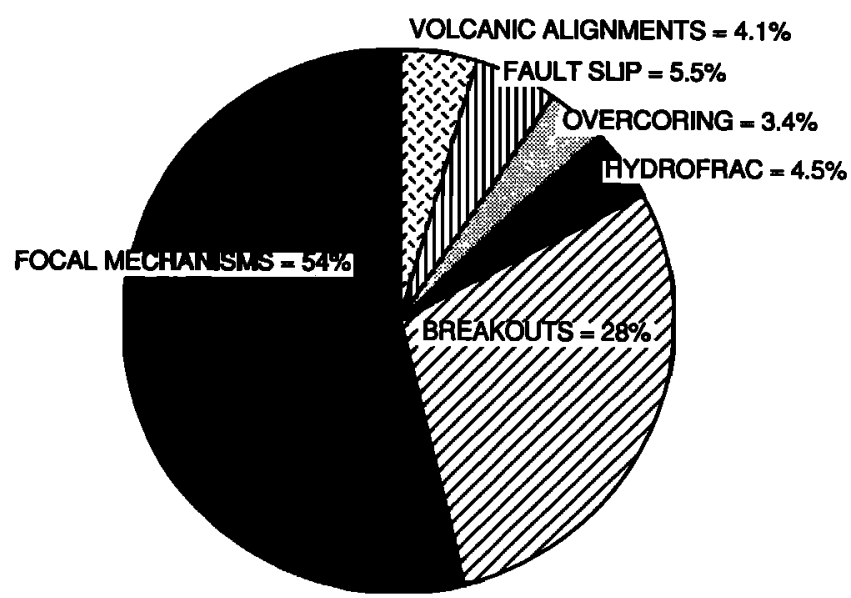

Fig. 2a. Distribution of reliable (A-C quality) data in WSM data base by type of stress indicator.

selected polarities for a series of randomly selected fault planes with slip vectors computed from a known stress tensor. The composite mechanisms that he created with this randomly generated data set closely replicated the initial stress tensor, provided there was enough diversity in his selected fault planes. Rivera and Cisternas [1990] provide a theoretical justification for such an approach and suggest an inversion of polarity observations (rather than nodal planes) to obtain deviatoric stress tensors, which are often close to the $P$ and $T$ axes of best fitting "composite" mechanisms. This inversion method holds much promise for obtaining additional regional stress data since it bypasses the need to invert individual fault planes from what may be relatively poorly constrained individual focal mechanisms.

The focal mechanism data provide valuable information on stress regime or relative magnitudes of the principal stresses. As described below, stress regime (or style of faulting) is defined on a set of criteria using the plunge of $P$, $B$, and $T$ axes.

Fault slip data. Young geologic fault slip data have been treated in a similar manner as the focal mechanism data. The highest-quality ranking is reserved for inversions of fault striations on fault planes with a variety of trends, the so-called "neotectonic analyses" pioneered by French structural geologists [Carey, 1979; Carey and Brunier, 1974; Angelier, 1979, 1984]. The slip vector and mean attitude of the fault plane for historic or prehistoric events are treated as paleofocal mechanisms with the $P$ axis inferred at $30^{\circ}$ to the known fault plane [after Raleigh et al., 1972] rather than the standard $45^{\circ}$ and are given a $B$ quality since these surface ruptures generally correspond to earthquakes with $m>$ 6.0-6.5 [e.g., Bonilla and Buchanan, 1970]. The C quality data represent a less accurate estimate of stress orientation, using only the strike of young faults and the primary sense of offset. For example, the trends of very young grabens are believed to indicate the orientation of the horizontal stresses to within $\pm 25^{\circ}$.

Stress directions inferred from the trends of joint sets are presently not considered in the WSM data base. Recent analyses of joint systems have shown that criteria can be defined for "neotectonic" joints based on field observations that may make them useful stress indicators. Such criteria include evidence for consistent extensional origin and vertical distribution. These neotectonic joint systems have been identified in several regions and are found to parallel directions of contemporary $S_{H_{\max }}$ directions inferred from other stress indicators [Hancock and Engelder, 1989; Hancock, 1991].

Borehole breakouts. Although breakout analysis was only established as a reliable stress determination technique in the late 1970s and early 1980s, it is significant that these data now comprise $28 \%$ of the data base (Figure $2 a$ ) and probably represent the greatest potential for producing new data in relatively aseismic areas. This stress determination technique utilizes the natural stress concentration around the borehole, which has been modeled as a hole in an elastic plate. Borehole breakouts represent shear failure of the borehole wall centered on the $S_{h \text { min }}$ direction, the azimuth of maximum circumferential compressive stress [see Gough and Bell, 1982; Zoback et al., 1985].

The analysis technique was first described by Cox [1970], and his initial analyses were extended to a greater number of wells by Babcock [1978]. Bell and Gough [1979] were the first to interpret these features as a stress-related phenomenon. Techniques for identification and interpretation of well bore breakouts have been described in numerous publications (see Bell [1990] and Zoback and Zoback [1991] for

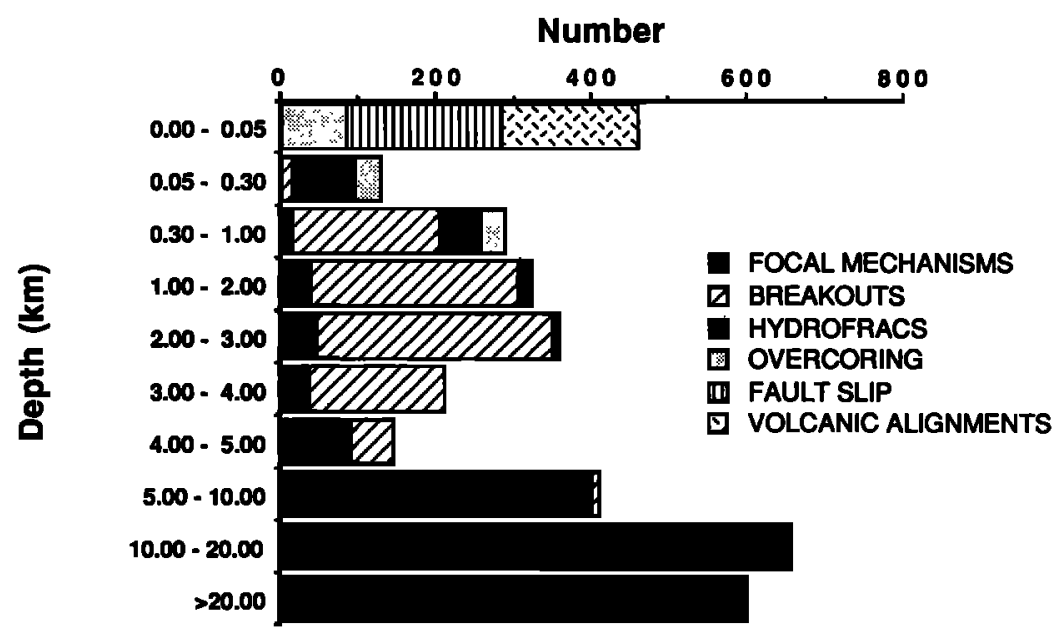

Fig. $2 b$. Depth distribution of reliable WSM data. 
useful summaries of references) and rely on analysis of the cross-sectional shape of a well bore through the use of a magnetically oriented four arm caliper tool (most common method) or an acoustic borehole televiewer [e.g., Plumb and Hickman, 1985].

Breakout data are especially important in this compilation because they generally sample a depth interval intermediate between earthquake focal mechanisms and in situ stress measurements and geologic data (see Figure $2 b$ ). They also provide multiple observations of stress orientations over considerable depth range. The large number of observations allows a statistical determination of stress orientation and its scatter about the mean especially when detailed analyses of breakouts are performed with borehole televiewers [e.g., Barton et al., 1988; Shamir et al., 1988]. In assessing quality we have tried to assure that multiple distinct breakout zones are sampled over a significant depth range. Note that $A$ quality results may result from averaging of stress orientations obtained from two or more wells in close proximity. Similarly, averages of wells in close proximity can be assigned a B or C quality if the combined number or length of breakouts and the standard deviation fit the range of values indicated.

Hydraulic fracturing stress measurements. This stress measurement technique also takes advantage of the stress concentration around the well bore and, ideally, provides determinations of both horizontal stress magnitudes and orientations [e.g., Haimson and Fairhurst, 1970; Zoback and Haimson, 1983]. Hydraulic fracturing is used in both engineering and scientific investigations and involves pressurizing a portion of the well bore until a tensile fracture develops striking in the direction of $S_{H \max }$, the azimuth of the minimum compressive circumferential stress. Interpretation of pressurization and pumping curves permits an accurate estimate of the magnitude of $S_{h \min }$ and limits on the magnitude of $S_{H \max }$. Vertical stress is typically assumed as equal to the weight of the overburden, and thus an approximate stress tensor can be determined. One disadvantage of this technique is that in order to make measurements of stress orientation, intact portions of the borehole must be tested, and it is sometimes difficult to detect the induced fracture.

However, a measurement technique called the Hydraulic Tests on Preexisting Fractures (HTPF) method utilizes pressurized reopening of preexisting fractures of a variety of trends to determine the stress field in a least squares sense [Cornet and Valette, 1984]. Cornet and Burlet [this issue] have used this technique in their investigation of the regional stress field in France.

Detailed hydraulic fracturing testing in a number of boreholes beginning very close to the surface (10-20 m depth) has revealed marked changes in stress orientation and relative magnitudes with depth in the upper few hundred meters possibly related to effects of nearby topography or a high degree of near-surface fracturing [e.g., Haimson, 1978]. As many hydraulic fracturing (hydrofrac) tests are done for engineering evaluation of stress conditions near dam sites or other structures, the reliability of these tests to record tectonic stress fields must be evaluated in terms of local site conditions. If this information is not available, we have taken a conservative approach and have generally given stress orientations obtained by hydraulic fracturing tests for a purely engineering study a D quality.
Volcanic vent alignments. The strike of dikes and the alignment of volcanic vents are considered to represent an analog of a natural massive hydrofrac experiment where the pressurizing fluid is magma, not water. The trend of the alignment should be perpendicular to $S_{h \min }$ [Nakamura, 1977; Nakamura et al., 1978]. Alignments may be inferred from linear zones of cinder cones or other vents or from the trends of feeder dikes. Often in the regions of youngest volcanism, not enough erosion has occurred to expose the underlying feeder dike system. All the data included in the data base have been dated as Quaternary in age either radiometrically or based on field relationships.

Two basic approaches have been utilized in analysis of volcanic alignment data: (1) Nakamura's method for defining the elliptical orientation of zones of eruptive vents on flanks and adjacent to active volcanoes and (2) simply identifying specific individual alignments in a field not dominated by a single large volcano. For Nakamura et al.'s [1978] data (primarily from the Aleutian arc in Alaska and a few points in Japan) we have used the same A-D quality ranking system they applied to their own data. In all other cases the volcanic alignment data in the data base come from analysis of individual vent alignments in a volcanic region, and qualities are assigned according to the criteria in Table 2 which are based both on the number and consistency of alignments within a given field.

A potential drawback with this technique is that nearsurface intrusions can sometimes utilize preexisting joint sets [Delaney et al., 1986]. However, as Delaney et al. indicate, these joint sets must strike nearly perpendicular to the current $S_{h \min }$ direction to accommodate the intrusion, so that errors in using dike orientation are likely to be small. An exception to this would be the case when the two horizontal stresses are approximately in magnitude, a condition with the general regional consistency of stress orientations in the WSM data base argues against as being common.

"Overcoring" stress measurements. Included in this category are a variety of stress or strain relief measurement techniques (see summary of these techniques by McGarr and Gay [1978] and a detailed summary by Engelder [1992]). These techniques involve three-dimensional measurement of the strain relief in a body of rock when isolated from the surrounding rock volume; the three-dimensional stress tensor can subsequently be calculated with knowledge of the complete compliance tensor for the rock. There are two primary drawbacks with this technique which restrict its usefulness as a tectonic stress indicator: measurements must be made near a free surface, and strain relief is determined over very small areas (a few square millimeters to square centimeters). Furthermore, near-surface measurements (by far the most common) have been shown to be subject to effects of local topography, rock anisotropy, and natural fracturing [Engelder and Sbar, 1984]. In addition, many of these measurements have been made for specific engineering applications (e.g., dam site evaluation, mining work), places where topography, fracturing, or nearby excavations could strongly perturb the regional stress field.

For all of the above reasons we have adopted a conservative quality ranking criterion to evaluate overcoring data. In cases where information is not available on the local site conditions we have assigned these data $\mathrm{D}$ quality (a large number of overcoring data in China and Korea fall into this category). In Fennoscandia, overcoring data believed to be 
TABLE 3. Stress Regime Characterization (and Method of Determining $S_{H \max }$ Azimuth) Based on Plunge (pl) of $P, B$, and $T$ Axes or $S_{1}, S_{2}$, and $S_{3}$ Axes

\begin{tabular}{|c|c|c|c|c|}
\hline \multicolumn{3}{|c|}{ Plunge of Axes } & \multirow[b]{2}{*}{ Regime } & \multirow[b]{2}{*}{$S_{H \max }$ Azimuth $^{a}$} \\
\hline$P / S_{1}$ & $B / S_{2}$ & $T / S_{3}$ & & \\
\hline $\begin{array}{l}\mathrm{pl} \geq 52^{\circ} \\
40^{\circ} \leq \mathrm{pl}<52^{\circ} \\
\mathrm{pl}<40^{\circ} \\
\mathrm{pl} \leq 20^{\circ} \\
\mathrm{pl} \leq 20^{\circ} \\
\mathrm{pl} \leq 35^{\circ}\end{array}$ & $\begin{array}{l}\mathrm{pl} \geq 45^{\circ} \\
\mathrm{pl} \geq 45^{\circ}\end{array}$ & $\begin{array}{l}\mathrm{pl} \leq 35^{\circ} \\
\mathrm{pl} \leq 20^{\circ} \\
\mathrm{pl} \leq 20^{\circ} \\
\mathrm{pl}<40^{\circ} \\
40^{\circ} \leq \mathrm{pl}<52^{\circ} \\
\mathrm{pl} \geq 52^{\circ}\end{array}$ & $\begin{array}{l}\text { NF } \\
\text { NS } \\
\text { SS } \\
\text { SS } \\
\text { TS } \\
\text { TF }\end{array}$ & $\begin{array}{l}\text { azimuth of } B \text { axis } \\
\text { azimuth of } T \text { axis }+90^{\circ} \\
\text { azimuth of } T \text { axis }+90^{\circ} \\
\text { azimuth of } P \text { axis } \\
\text { azimuth of } P \text { axis } \\
\text { azimuth of } P \text { axis }\end{array}$ \\
\hline
\end{tabular}

${ }^{a}$ For some overcoring and hydraulic testing of preexisting fractures measurements, the magnitudes of the full stress tensor are determined and the $S_{H \max }$ azimuth can be calculated directly from the eigenvectors of the tensor. However, the stress regime characterization in these cases is still based on the plunges of the principal axes.

influenced by overlying or adjacent excavations in mines were simply not included in the WSM data base since a complete compilation of these data are available in Fennoscandian rock stress data base [Stephansson et al., 1987]. The Fennoscandian overcoring data included in the WSM data base were those assessed to be uncontaminated by local site effects by $O$. Stephansson (Lulea University, Sweden). Similarily, "reliable" overcoring data from mines in the Ural Mountains of Russia were compiled by P. Kropotkin (Geological Institute, Russian Academy of Sciences, written communication, 1990) and from mines in South Africa by $\mathbf{N}$. Gay (COMRO, Rock Engineering Division, written communication, 1990), although detailed information of local conditions was not available.

There have been a number of shallow overcoring measurements carried out specifically to investigate the regional stress field. In these cases, care was taken to avoid sites with nearby topography and/or extensive joint or fracture systems, and depths were believed sufficient to avoid thermal effects. A summary of such measurements made in western Europe is presented by Becker and Paladini [1991]. As indicated in Table 2, these well-controlled near-surface measurements (depths generally between 5 and $10 \mathrm{~m}$ ) were assigned a $\mathrm{C}$ quality.

\section{Relative Stress Magnitudes and Determination of Stress Regimes}

While meaningful absolute stress magnitude information (made at depths $>100 \mathrm{~m}$ ) was available for only about $4 \%$ of the data in the data base $(1.1 \%$ from shallow overcoring measurements and $3.1 \%$ from hydrofracs), information on relative stress magnitudes or stress regime could be inferred from the more numerous focal mechanism and fault slip data. In addition, an extensional stress regime was assigned to volcanic alignment data in the western United States and in Mexico on the basis of Quaternary normal faulting associated with these young basaltic volcanic fields.

Throughout this paper, stress magnitudes are defined using the standard geologic/geophysical notation with compressive stresses positive, so that $S_{1}>S_{2}>S_{3}$ indicates that $S_{1}$ is the maximum principal compressive stress and $S_{3}$ is the minimum principal compressive stresses. Following Anderson [1951], three stress regime categories can be defined on the basis of relative stress magnitudes: extensional stress regime $\left(S_{v}>S_{H \max }>S_{h \min }\right)$, corresponding to normal dip-slip faulting; strike-slip stress regime $\left(S_{H \max }>\right.$
$\left.S_{v}>S_{h \min }\right)$, corresponding to faulting with dominantly horizontal slip; and a thrust faulting stress regime $\left(S_{H_{\max }}>\right.$ $S_{h \min }>S_{v}$, corresponding to reverse dip-slip faulting. In some areas, the stress field appears to be transitional between regimes; that is, two of the stresses are approximately equal in magnitude. A stress field of the form $\mathrm{Sv} \approx S_{H \max } \gg$ $S_{h \text { min }}$ can produce a combination of both normal and strikeslip faulting, whereas a stress field of the form $S_{H \max } \gg$ $S_{h \text { min }} \approx S_{v}$ produces a combination of strike-slip and thrust faulting. Other possible end-members for stress magnitudes $\left(S_{H \max }=S_{h \min }\right)$ produce radial compression or radial extension depending on whether the horizontal stresses are greater than or less than the vertical stress, respectively. As mentioned above, while such a horizontally isotropic stress state may exist in some places [Haimson, 1984; Zoback, 1989; Adams, 1989], the regional uniformity of $S_{H \max }$ orientations argues that such stress states are not common in the Earth's crust.

For the WSM data base we have used plunges of measured $S_{1}, S_{2}, S_{3}$ axes or $P, T$, and $B$ axes to divide the data into five main stress regime categories. In addition, an unknown category is used when the data provide no information about relative stress magnitudes (e.g., well bore breakout data). The stress regime categories include normal faulting (NF), predominately normal with strike-slip component (NS), strike-slip faulting (includes minor normal or thrust component) (SS), thrust faulting (TF), predominately thrust with strike-slip component (TS), and unknown (U). The cutoff values for plunges of $P, T$, and $B$ axes (or $S_{1}, S_{2}$, and $S_{3}$ ) for these various categories are given in Table 3 together with the choice of axes used in the data base to infer the maximum horizontal stress $\left(S_{H \max }\right)$ orientation. For example, the $S_{H \max }$ orientation is taken as the azimuth of the $B$ axis in case of a pure normal faulting regime (NF) and as $\left(90^{\circ}\right.$ $+T$ axis azimuth) in the NS case when the $B$ axis generally plunges more steeply than the $T$ axis.

While the exact cutoff values defining the stress regime categories are subjective, we have attempted the broadest possible categorization consistent with actual $P, T$, and $B$ axes values. The NS and TS categories represent mixedmode faulting. In these two categories, either the minimum stress or $T$ axis (normal faulting) or the maximum stress or $P$ axis (thrust faulting) is approximately horizontal, and the vertical and other horizontal axes rotate in a perpendicular plane. NS is distinguished from SS by virtue of the fact that the maximum stress or $P$ axis is the steeper plunging of the 

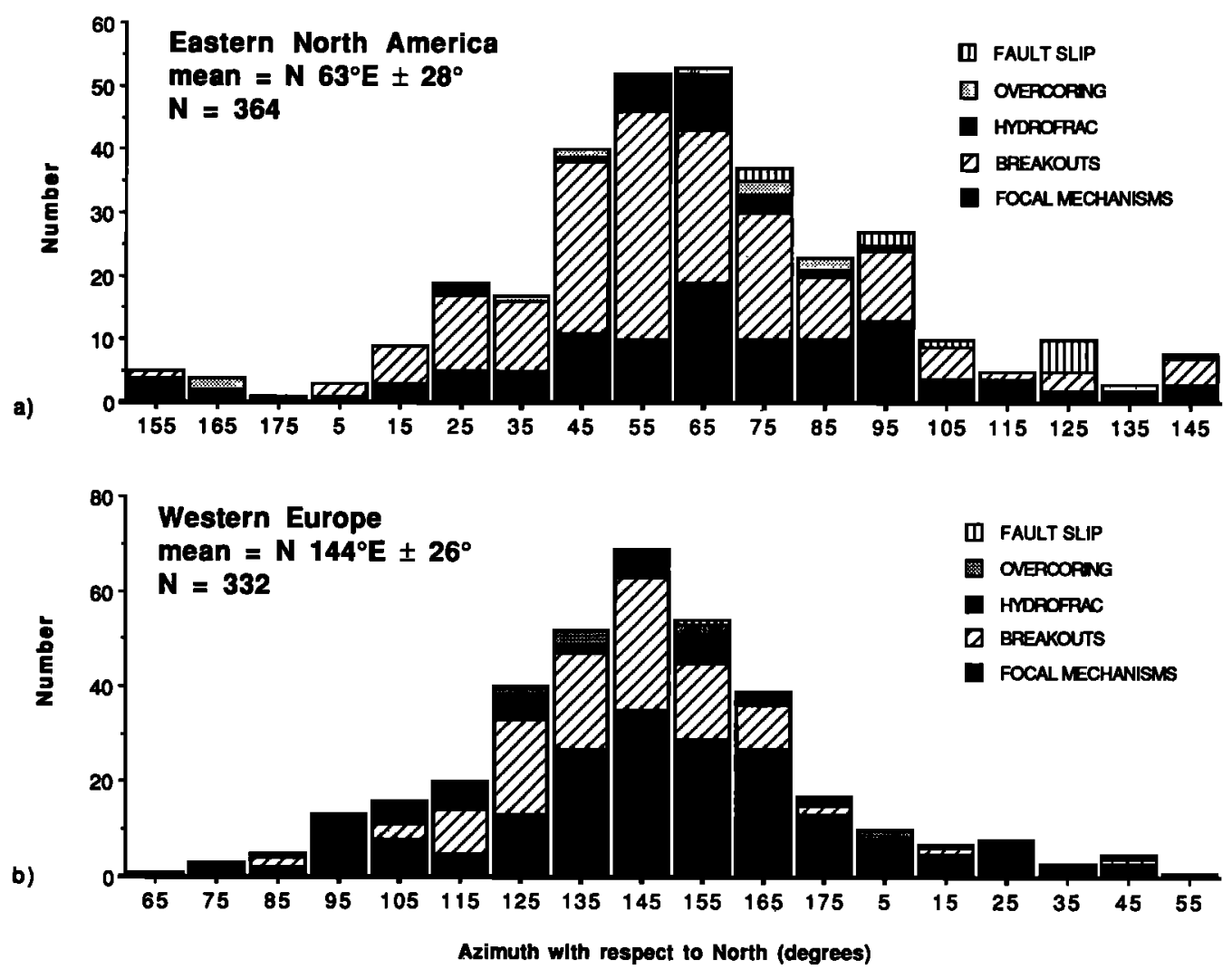

Fig. 3. Histogram of reliable $S_{H \max }$ orientations broken down by type of indicator. (a) Eastern North America (region between $31.5^{\circ}$ and $51^{\circ} \mathrm{N}$ latitude, $55^{\circ}$ and $100^{\circ} \mathrm{W}$ longitude). (b) Western Europe (region between $46.2^{\circ}$ and $55^{\circ} \mathrm{N}$ latitude, $10^{\circ} \mathrm{W}$ and $17^{\circ} \mathrm{E}$ longitude).

$P$ and $B$ axes, and similarly, TS is distinguished from SS by the fact that the minimum stress or $T$ axis is the steeper plunging of the $B$ and $T$ axes (see Table 3).

Plunges of axes of some of the data fall outside of the ranges defined in Table 3 . When the differences were only a few degrees, these data were inspected individually and assigned to the most appropriate category. However, a number of mechanisms, notably for smaller and often less well constrained focal mechanisms, had $P, B$, and $T$ axes which did not fit at all into the defined categories. The anomalous mechanisms fell in two main groups: (1) all three axes have moderate plunges (between $25^{\circ}$ and $45^{\circ}$ ) or (2) both $P$ and $T$ axes have nearly identical plunges, in the range of $40^{\circ}-50^{\circ}$. In both cases it is difficult to infer the true maximum and minimum horizontal stress azimuths. These data points may represent deformation due to principal stress fields tilted out of horizontal and vertical planes. The data which fell into this category compose less than $2 \%$ of all focal mechanisms and were assigned an $U$ (unknown) stress regime and given an $\mathrm{E}$ quality, indicating that the maximum horizontal stress azimuth was not well defined.

\section{General Characteristics of the Data Base}

As of December 1991, 7328 stress data were compiled as part of the World Stress Map project, 1141 of these were E quality with no reliable information on stress information. Of the remaining 6214 entries, 4413 are considered to yield reliable information on tectonic stress orientations (A-C quality) and are plotted on Figure 1 and on the large, folded color map (Plate 1). As mentioned above, the distribution of the data in the data base by stress measurement technique is shown in Figure $2 a$. Figure $2 b$ gives the depth distribution of the A-C quality data: the geologic and in situ stress measurement data are generally restricted to the surface or very near surface (less than 1-2 km depth), earthquake focal mechanisms provide coverage for depths between about 5 and $20 \mathrm{~km}$, and well bore breakout data (which come primarily from petroleum exploration wells) commonly sample $1-4 \mathrm{~km}$ deep and in some cases as deep as 5-6 km, providing a valuable link between the near-surface and the focal mechanism data. It is also important to note that the breakout and in situ stress measurement data provide valuable information on the stress field in nonactive (nonseismic regions).

As can be seen on Figure 1 and Plate 1, there are a number of regions of very uniform $S_{H \max }$ orientations: eastern North America, western Canadian Basin (region directly east of the Canadian Rockies), central California, the Andes, western Europe, the Aegean, and northeastern China. Detailed analysis of the stress directions within these regions of uniform coverage indicates that stress orientation inferred from different types of indicators yield consistent orientations. Figure 3 plots stress orientations broken down by different indicator type for two very large regions: eastern North America (between latitude $31.5^{\circ}$ and $51^{\circ} \mathrm{N}$ and longitude $55^{\circ}$ and $100^{\circ} \mathrm{W}$ ) (Figure $3 a$ ); and western Europe (between latitude $46.2^{\circ}$ and $55^{\circ} \mathrm{N}$ and longitude $10^{\circ} \mathrm{W}$ and $17^{\circ} \mathrm{E}$ ) (Figure $3 b$ ). Assumpcao [this issue] has made a similar comparison for the Andes. In both areas shown in Figure 3 there is a well-defined mean $S_{H \max }$ direction indicated, although there 
is considerable scatter about this mean and this scatter appears in all data types over these broad regions. Many small regions in Figure 1 and Plate 1 show an excellent correlation between the different stress measurement techniques, indicating that the criteria defined in Table 2 are resulting in consistent determinations of the tectonic stress field despite the different volumes of rock and different depth intervals sampled.

\section{First-Order Global Stress Patterns}

In addition to stress orientations, relative stress magnitudes (stress regimes) are indicated on Plate 1 using the following definitions: extensional stress regime $\left(S_{v}>S_{H \max }\right.$ $>S_{h}$ ) (normal dip slip), includes categories NF and NS (rakes generally $\left.>50^{\circ}\right)$; strike-slip stress regime $\left(S_{H \max }>S_{v}\right.$ $>S_{h}$ ) (dominant horizontal slip), SS category (rakes generally $\left.>40^{\circ}\right)$; and thrust stress regime $\left(S_{H \max }>S_{h}>S_{v}\right)$ (reverse dip slip), includes categories TF and TS (rakes generally $>50^{\circ}$ ).

The data shown in Figure 1 and Plate 1 reinforce the broad-scale patterns and general conclusions regarding the global data base summarized by Zoback et al. [1989]:

1. In most places a uniform stress field exists throughout the upper brittle crust as indicated by consistent orientations from the different techniques which sample very different rock volumes and depth ranges.

2. The interior portions (variously called intraplate and midplate regions) are dominated by compression (thrust and strike-slip stress regimes) in which the maximum principal stress is horizontal.

3. Active extensional tectonism (normal faulting stress regime) in which the maximum principal stress is vertical generally occurs in topographically high areas in both the continents and the oceans.

4. Regional consistency of both stress orientations and relative magnitudes permits the definition of broad-scale regional stress provinces, many of which coincide with physiographic provinces, particularly in tectonically active regions.

This final point, regionally uniform stress orientations and relative magnitudes, is emphasized in a generalized global stress map shown in Figure 4, which shows mean stress directions and dominant stress regime for clusters of data plotted on Figures 1 and Plate 1. The arrow sizes on Figure 4 represent a subjective assessment of "quality" related to the degree of uniformity of stress orientation and also to the number and density of data. Stress regime was inferred primarily from earthquake focal mechanisms and style of Quaternary faulting. Thick inward pointing arrows indicate $S_{H \max }$ orientations in areas of compressional (strike-slip and thrust) stress regimes. Thick outward pointing arrows give $S_{h \min }$ orientations in areas of normal faulting regimes. Regions dominated by strike-slip tectonics are distinguished with the thick inward pointing arrows and orthogonal, thin outward pointing arrows.

The broad regions of the Earth's crust subjected to uniform stress orientation or a uniform pattern of stress orientation (such as the radial pattern of stress orientations in China) are referred to in this paper as "first-order" stress provinces. These regions and the stress orientation patterns are briefly summarized plate by plate in Table 4, which also serves as a guide to the generalized map shown in Figure 4.
The most recent references for detailed descriptions of the regional stress fields are also given in Table 4.

Some regional stress patterns listed in Table 4 are newly defined (i.e., not discussed by Zoback et al. [1989]) and merit brief discussion. In particular, the existence of a region in western and north central Africa of compressional tectonism with an approximately E-W $S_{H \max }$ orientation has been identified on the basis of new data. These data include focal mechanisms determined from waveform modeling of largemagnitude earthquakes occurring in west Africa between 1939 and 1983 [Suleiman et al., 1989; D. I. Doser, written communication, 1990] as well as some recent CMT solutions which all show a consistent pattern of strike-slip deformation with a roughly E-W $P$ axes orientation. An approximately E-W $S_{H \max }$ orientation is also observed in breakout data from 11 wells covering a region over $1000 \mathrm{~km}$ wide in the Sudan [Bosworth et al., this issue]. In addition, a zone of NNW compression is identified along the northern boundary of the African plate consistent with the convergence of Africa and Eurasia.

As noted by Zoback et al. [1989], the plate tectonic setting of Africa (surrounded by mid-ocean ridges and a continental collision to the north) suggests a midplate compressional stress field. Buoyancy forces related to asthenospheric upwelling and lithospheric thinning in the east Africa rift system clearly dominate the stress field in that area. However, the new data suggests that a regional intraplate stress field related to plate-driving forces may exist outside of the area of high topography and asthenospheric upwelling. As discussed below in the section on second-order stresses, the amount of rotation of the horizontal stress directions between west African and the east African rift places a strong constraint on the ratio of the magnitudes of the regional stresses relative to the local buoyancy forces, suggesting that the horizontal extensional buoyancy stress must be about 1.2 times the magnitude of the regional horizontal stress differences.

One place where stress patterns have been recently clarified somewhat is in Australia. Stress orientations there still show a great deal of scatter; however, additional breakout data on the NW continental shelf [Hiller, 1991], the occurrence of the three $M_{s}=6.3-6.7$ earthquakes in the 1988 Tennant Creek region [Choy and Bowman, 1990], and a reassessment of the quality of several moderate-magnitude, relatively poorly constrained thrust faulting focal mechanisms, recorded only locally, has clarified the stress patterns somewhat. In particular, much of central and northeastern Australia indicates a compressional stress field dominated by NNE compression, whereas available data from both southeastern and southwestern Australia indicate E-W compression.

By contrast, as can be seen on Figure 1 and Plate 1 , the extents of some regions of relatively uniform $S_{H \max }$ orientation are enormous. The region of uniform ENE $S_{H \max }$ orientation in midplate North American covers nearly the entire continental portion of the plate lying at an average elevation of less than $1000 \mathrm{~m}$ (excluding the west coast) and may also extend across much of the western Atlantic basin [Zoback et al., 1986]. Thus here the stress field is uniform over roughly $5000 \mathrm{~km}$ in both an E-W direction and a N-S direction. In western Europe the region of relatively uniform NW $S_{H \max }$ orientation extends over $1500 \mathrm{~km}$ in an E-W direction and about $2200 \mathrm{~km}$ in a N-S direction. 

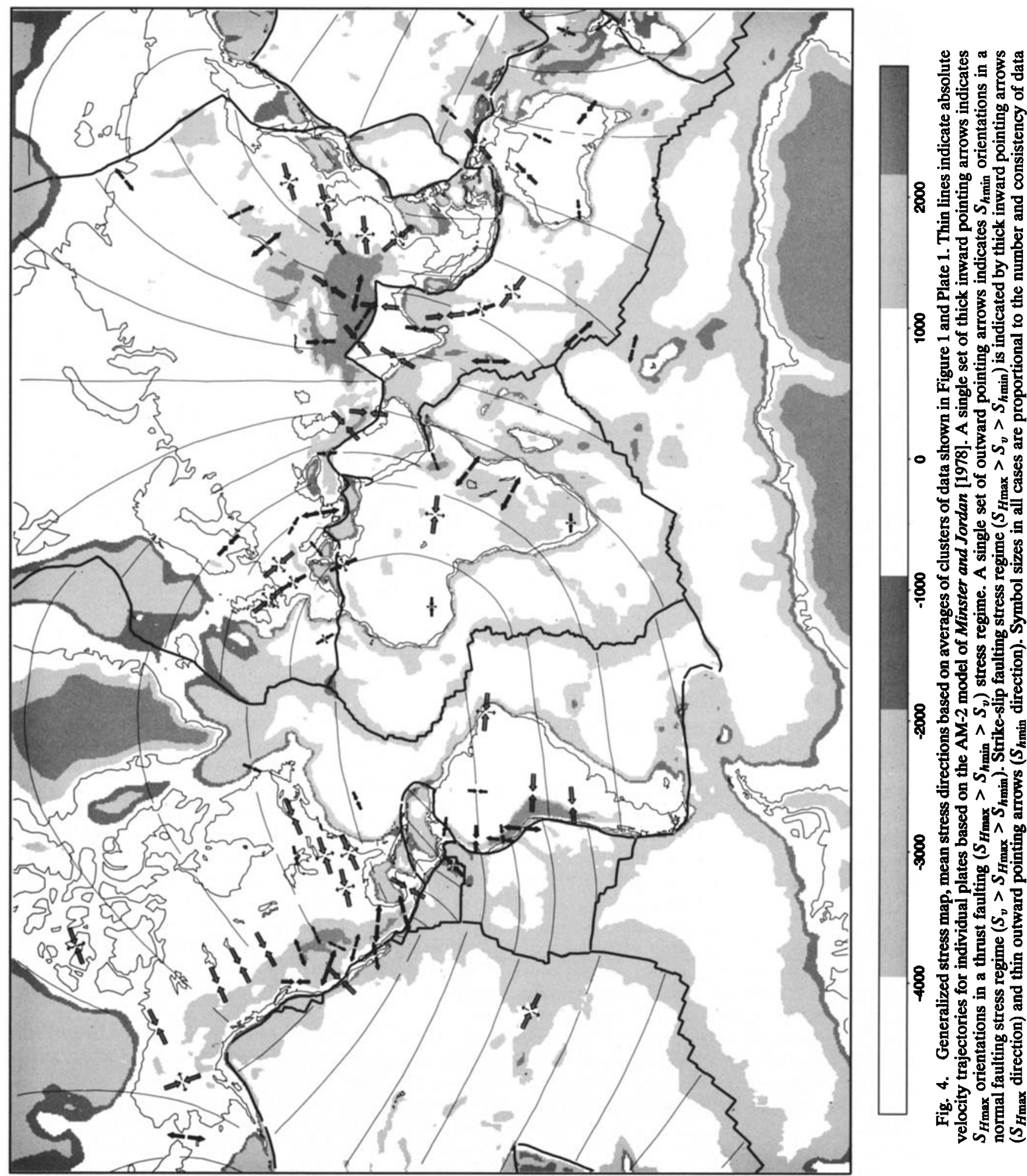

8 它

实

击 \&

记

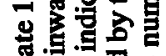

递尊

8

过野

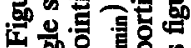

a.

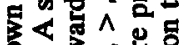

- 总安的家

焉氞桴

ठ

跑

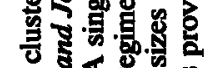

\%

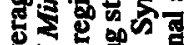

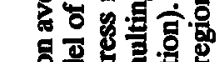

可雾密

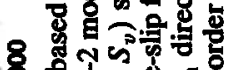

ชิ

.

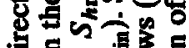

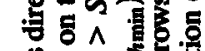

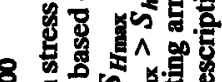

8 \%

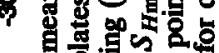

을 $\wedge$ 宥

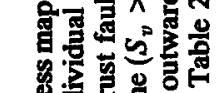

8

8 \%

\%

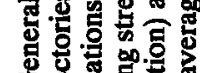

S.

+ 近

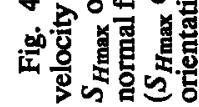


TABLE 4. First-Order Global Stress Patterns

\begin{tabular}{|c|c|c|c|c|c|}
\hline \multirow[b]{2}{*}{ Region } & \multirow{2}{*}{$\underset{S_{h \max } \text { or }}{S_{S_{\min }}}$} & \multirow{2}{*}{$\begin{array}{c}\text { Stress } \\
\text { Regime }^{b}\end{array}$} & \multirow{2}{*}{$\begin{array}{c}\text { Primary Source of Stress } \\
\text { and Comments }\end{array}$} & \multicolumn{2}{|c|}{ References } \\
\hline & & & & State of Stress & Stress Modeling \\
\hline Midplate region & ENE & $\mathrm{T} / \mathrm{SS}$ & $\begin{array}{l}\text { North American Plate } \\
\text { primarily ridge push, lateral } \\
\text { stress variations predicted } \\
\text { for basal drag not } \\
\text { observed, regionally } \\
\text { extensive }\left(\sim 2 \times 10^{7} \mathrm{~km}^{2}\right)\end{array}$ & $\begin{array}{l}\text { Adams and Bell [1991] and } \\
\text { Zoback and Zoback } \\
{[1989,1991]}\end{array}$ & $\begin{array}{l}\text { Richardson and Reding } \\
\text { [1991] }\end{array}$ \\
\hline $\begin{array}{l}\text { Western Cordillera, } \\
\text { Central America, } \\
\text { and Alaska }\end{array}$ & & & $\begin{array}{l}\text { complex stress patterns } \\
\text { beyond scope of } \\
\text { discussion, largely related } \\
\text { to superposition of } \\
\text { buoyancy forces and } \\
\text { distributed shear related to } \\
\text { Pacific-North American } \\
\text { relative motion }\end{array}$ & $\begin{array}{l}\text { many references, see } \\
\text { summaries by Zoback } \\
\text { and Zoback [1989, } \\
\text { 1991], Suter [1991], } \\
\text { Suter et al. [this issue], } \\
\text { and Estabrook and } \\
\text { Jacob [1991] }\end{array}$ & \\
\hline Continental & $\mathrm{E}$ & $\mathrm{T} / \mathrm{SS}$ & $\begin{array}{l}\text { South American Plate } \\
\text { primarily ridge push, torque } \\
\text { analysis suggests driving } \\
\text { drag possibly major force } \\
\text { [Meijer and Wortel, this } \\
\text { issue] }\end{array}$ & Assumpcao [this issue] & $\begin{array}{l}\text { Stefanick and Jurdy [this } \\
\text { issue] and Meijer and } \\
\text { Wortel [this issue] }\end{array}$ \\
\hline High Andes & $\mathbf{N}$ & NF & $\begin{array}{l}\text { trench suction or buoyancy } \\
\text { due to thick crust and/or } \\
\text { thinned lithosphere }\end{array}$ & $\begin{array}{l}\text { Froidevaux and Isacks } \\
\text { [1984] and Mercier et al. } \\
\text { [this issue] }\end{array}$ & $\begin{array}{l}\text { Whittaker et al. [this } \\
\text { issue] and Stefanick } \\
\text { and Jurdy [this issue] }\end{array}$ \\
\hline Western Europe & NW & SS & $\begin{array}{l}\quad \text { Eurasian Plate } \\
\text { combined effects of ridge } \\
\text { push and continental } \\
\text { collision with Africa } \\
\text { dominate, absolute } \\
\text { velocity } \approx 0 \text {; thus } \\
\text { resistive or driving basal } \\
\text { drag probably not } \\
\text { important; lateral } \\
\text { variations in lithospheric } \\
\text { structure may locally } \\
\text { influence stress field }\end{array}$ & $\begin{array}{l}\text { Klein and Barr [1987], } \\
\text { Gregersen [this issue], } \\
\text { Grünthal and Stromeyer } \\
\text { [this issue], and Müller } \\
\text { et al. [this issue], and } \\
\text { Rebai et al. [1992] }\end{array}$ & $\begin{array}{l}\text { Brudy [1990] and } \\
\text { Günthal and } \\
\text { Stromeyer [this issue] }\end{array}$ \\
\hline China/eastern Asia & $\mathbf{N}$ to $\mathbf{E}$ & SS & $\begin{array}{l}\text { continental collision force } \\
\text { domimates, indentor } \\
\text { geometry extremely } \\
\text { important }\end{array}$ & $\begin{array}{l}\text { Molnar and Tapponnier } \\
\text { [1975], Molnar and } \\
\text { Deng [1984], and } X u \text { et } \\
\text { al. [this issue] }\end{array}$ & $\begin{array}{l}\text { England and Houseman } \\
\text { [1989], Tapponnier } \\
\text { and Molnar [1976], } \\
\text { and Vilotte et al. } \\
\text { [1984, 1986] }\end{array}$ \\
\hline Tibetan Plateau & WNW & NF & $\begin{array}{l}\text { Buoyancy (due to thick crust } \\
\text { and/or thinned upper } \\
\text { mantle) overcomes } \\
\text { compression due to } \\
\text { continental collision force }\end{array}$ & $\begin{array}{l}\text { Molnar and Tapponnier } \\
\text { [1978], Mercier et al. } \\
\text { [1987b], and Burchfiel } \\
\text { and Royden [1985] }\end{array}$ & $\begin{array}{l}\text { England and Houseman } \\
\text { [1989] and Vilotte et } \\
\text { al. [1986] }\end{array}$ \\
\hline East African rift & NW & NF & $\begin{array}{c}\text { African Plate } \\
\text { Buoyancy force overcomes } \\
\text { ridge push compression }\end{array}$ & Bosworth et al. [this issue] & \\
\hline $\begin{array}{l}\text { Midplate (western and } \\
\text { southern Africa) }\end{array}$ & $\mathbf{E}$ & SS & $\begin{array}{l}\text { ridge push dominates } \\
\text { absolute velocity } \approx 0 ; \\
\text { thus drag probably not } \\
\text { important }\end{array}$ & $\begin{array}{l}\text { this paper, using data of } \\
\text { Bosworth et al. [this } \\
\text { issue], Suleiman et al. } \\
\text { [1989], and D. I. Doser } \\
\text { (written communication, } \\
\text { 1990) }\end{array}$ & \\
\hline North Africa & $\mathrm{N}$ to $\mathrm{NW}$ & T/SS & $\begin{array}{l}\text { continental collision with } \\
\text { Europe dominates }\end{array}$ & $\begin{array}{l}\text { Rebai et al. [1991] and } \\
\text { Kamoun and Hfaiedh } \\
\text { [1985] }\end{array}$ & \\
\hline India & $\mathrm{N}$ to $\mathrm{NE}$ & T/SS & $\begin{array}{l}\text { Indian Australian Plate } \\
\text { continental collsion }\end{array}$ & Gowd et al. [this issue] & $\begin{array}{l}\text { Cloetingh and Wortel } \\
{[1985,1986]}\end{array}$ \\
\hline Central Indian Ocean & $\mathrm{N}$ to $\mathrm{NW}$ & T/SS & $\begin{array}{l}\text { complex interaction collision } \\
\text { and trench forces, long- } \\
\text { wavelength basement } \\
\text { undulations due to stress- } \\
\text { induced flexure? }\end{array}$ & $\begin{array}{l}\text { Bergman [1986], C. Stein } \\
\text { et al. [1989], and Petroy } \\
\text { and Wiens [1989] }\end{array}$ & $\begin{array}{l}\text { Cloetingh and Wortel } \\
\text { [1985, 1986] and Gover } \\
\text { et al. [this issue] }\end{array}$ \\
\hline
\end{tabular}


TABLE 4. (continued)

\begin{tabular}{|c|c|c|c|c|c|}
\hline \multirow[b]{2}{*}{ Region } & \multirow{2}{*}{$\underset{\substack{S_{h \max } \text { or } \\
\text { Orientation }}}{S^{a}}$} & \multirow{2}{*}{$\begin{array}{c}\text { Stress } \\
\text { Regime }^{b}\end{array}$} & \multirow{2}{*}{$\begin{array}{l}\text { Primary Source of Stress } \\
\text { and Comments }\end{array}$} & \multicolumn{2}{|c|}{ References } \\
\hline & & & & State of Stress & Stress Modeling \\
\hline \multicolumn{6}{|c|}{ Indian Australian Plate (continued) } \\
\hline West Indian Ocean & $\mathrm{N}$ to $\mathrm{NW}$ & NF & $\begin{array}{l}\text { high level of intraplate } \\
\text { seismicity with } S_{h \text { min }} \\
\text { parallel to nearby mid- } \\
\text { ocean ridges, due to } \\
\text { thermoelastic stresses or } \\
\text { comple geometry of } \\
\text { plate-driving forces? }\end{array}$ & $\begin{array}{l}\text { Bergman et al. }[1984], \\
\text { Wiens and Stein }[1984] \\
\text { and Stein et al. }[1987]\end{array}$ & $\begin{array}{l}\text { Cloetingh and Wortel } \\
\text { [1985,1986], Bratt et al. } \\
\text { [1985], and Gover et al. } \\
\text { [this issue] }\end{array}$ \\
\hline $\begin{array}{l}\text { Central Australia and } \\
\text { northwest shelf }\end{array}$ & $\mathrm{N}$ to $\mathrm{NE}$ & TF & $\begin{array}{l}\text { much scatter in stress } \\
\text { orientations; however, } \\
\text { best data suggest } \\
\text { consistent north to } \\
\text { NNE } S_{H \max } \text { directions }\end{array}$ & this paper & $\begin{array}{l}\text { Cloetingh and Wortel } \\
{[1985,1986]}\end{array}$ \\
\hline $\begin{array}{l}\text { Southern coastal } \\
\text { Australia }\end{array}$ & $\mathrm{E}$ & TF & $\begin{array}{l}\text { source of E-W stress } \\
\text { unknown }\end{array}$ & & \\
\hline Young $(<70)$ crust & $\mathrm{NE}$ & SS & $\begin{array}{l}\text { Pacific Plate } \\
\text { ridge push, slab pull, drag } \\
\text { all give same orientation }\end{array}$ & $\begin{array}{l}\text { Okal et al. [1980] and } \\
\text { Wiens and Stein [1984] }\end{array}$ & $\begin{array}{l}\text { Richardson et al. [1979], } \\
\text { Bai et al. [this issue], } \\
\text { Wortel et al. [1991], and } \\
\text { Gover et al., [this issue] }\end{array}$ \\
\hline Older crust $(>70)$ & NW? & $\mathrm{T} / \mathrm{SS}$ & $\begin{array}{l}\text { driving drag would predict } \\
\text { extension, not observed } \\
\text { compression; extension } \\
\text { predicted due to mantle } \\
\text { upwelling central Pacific } \\
\text { also not observed }\end{array}$ & $\begin{array}{l}\text { Wiens and Stein [1985] } \\
\text { and Zoback et al. }\end{array}$ & $\begin{array}{l}\text { Richardson et al. [1979], } \\
\text { Bai et al. [this issue], } \\
\text { Wortel et al. [1991], and } \\
\text { Gover et al. [this issue] }\end{array}$ \\
\hline Midplate & $?$ & $?$ & $\begin{array}{l}\text { Nazca Plate } \\
\text { only one earthquake focal } \\
\text { mechanism available }\end{array}$ & & $\begin{array}{l}\text { Wortel and Cloetingh } \\
\text { [1985] and Richardson } \\
\text { and Cox [1984] }\end{array}$ \\
\hline Midplate & $?$ & $?$ & \begin{tabular}{l}
\multicolumn{1}{l}{ Antarctic Plate } \\
expected stress state is \\
radial compression \\
(surrounded by ridges), \\
one focal mechanism \\
available, seismicity \\
suppressed by ice \\
sheet?
\end{tabular} & Johnston [1987] & \\
\hline West Antarctic rift & E to NE & NF & $\begin{array}{l}\text { Cenozoic rift system with } \\
\text { basalts as young as } \\
\text { Holocene; buoyancy } \\
\text { forces dominate } \\
\text { midplate compression }\end{array}$ & $\begin{array}{l}\text { Behrendt et al. [1991] and } \\
\text { Behrendt and Cooper } \\
\text { [1991] }\end{array}$ & \\
\hline
\end{tabular}

\footnotetext{
${ }^{a} S_{H \max }$ orientation given for thrust or strike-slip faulting stress regimes; $S_{h \min }$ given for normal faulting stress regimes.

${ }^{b} \mathrm{NF}$, normal faulting stress regime; SS, strike-slip faulting stress regime; TF, thrust fauting stress regime; T/SS, combined thrust and strike-slip regimes (see text for definitions of stress regimes).
}

The likely sources of broad-scale stress fields are related to plate tectonic driving forces. Following Forsyth and Uyeda [1975] and Chapple and Tullis [1977], a series of body forces and tractions are defined as acting along plate boundaries. The primary forces that either drive or resist plate motion include slab pull, ridge push (actually a distributed force acting over the entire portion of cooling oceanic lithosphere thickening with age), collisional resistance, trench suction, and basal drag. Analysis of relative magnitudes of the plate-driving forces based on balancing the net torque acting on each plate [Forsyth and Uyeda, 1985; Chapple and Tullis, 1977] indicates that the two largest forces acting on the plates are the negative buoyancy of the subducting slab and the resistance to subduction (both viscous and friction). They conclude that the net slab force, the sum of these two forces, is small and cannot be distin- guished from the other possible forces acting on the plate. (See, for example, Stefanick and Jurdy [this issue], Richardson [this issue], and Richardson and Reding [1991] for summaries of the sources and relative magnitudes of the plate-driving forces.)

For purposes of evaluating the broad-scale patterns of intraplate stresses it is important to keep in mind that the net slab pull, collisional resistance, and trench suction forces all act normal to plate boundaries and that ridge push forces act in a direction perpendicular to the isochrons in oceanic lithosphere. Ridge push and collisional resistance generate intraplate compression; trench suction results in intraplate extension. The sign of the net slab force has been estimated as a function of age [Cloetingh and Wortel, 1986] and is generally extensional and perpendicular to the trench. The effects of drag forces are more difficult to estimate because 
there are several possible configurations: resistive drag at the base of the plate opposing plate motions, driving drag in the direction of plate motion, drag due to "counterflow" (mass flow from trenches back to ridges), and drag due to deep mantle flow. Drag resisting or driving plate motions should generate stresses aligned with the absolute plate motion directions. A clear disagreement between observed ENE compression in eastern North America and NW-SE directed counterflow predicted beneath that region [Chase, 1979; Hager and O'Connell, 1979] implies either that the counterflow must occur at a level too deep to influence stress state in the lithosphere [Zoback et al., 1986] or that the shear coupling between this counterflow and the lithosphere is quite weak. Bai et al. [this issue] provide some estimates of the stress effect in the lithosphere due to deep mantle flow.

Zoback et al. [1989] demonstrated a correlation between $S_{H \max }$ orientation and the azimuth of both absolute and relative plate velocities (using histograms of point by point comparisons) for several intraplate regions (see Figure 4 for regions of correlation). However, as demonstrated by Richardson [this issue], the ridge push torque pole is very similar to the absolute velocity pole for most plates; thus a comparison with absolute velocity trajectories can do little to distinguish between ridge push and basal drag as a source of stress. In fact, comparison between stress directions and local azimuths computed from velocity poles is an overly simplistic approach to evaluating the influence of platedriving force on the intraplate stress field. At best, these correlations demonstrate the important role of the plate boundary forces and can be used to conclude that the net balance of forces driving the plates also stresses them [Zoback et al., 1989]. The actual orientation of the intraplate stress field of course depends on the balance of forces acting on the plate and the plate geometry on which they act and can only accurately be predicted by detailed modeling (such as finite element modeling).

Much of our knowledge of the relative magnitudes of the various plate-driving forces comes from modeling of the kinematics of plate motions. However, as Stefanick and Jurdy [this issue] point out, there is an inherent problem with this kinematic approach; because the motion of a rigid plate is the result of the integrated effect of all torques acting on it, different combinations of forces (with the same net torque) can produce the same plate motion. Numerous finite element modeling attempts (beginning with the global models of Richardson et al. [1979]) have demonstrated that knowledge of the first-order intraplate stress orientations and relative stress magnitudes (stress regimes) is a powerful constraint in constraining force models. Table 4 also includes a summary of the results of this finite element modeling of the intraplate stress field by various investigators (many included in this special section) and provides an assessment of the relative role of the various plate tectonic forces in determining the intraplate stress field, based on the correlations with observed orientations and relative magnitudes as well as the modeling results.

The first-order stress patterns shown in Figure 4 and described in Table 4 provide constraints on the relative importance of various broad-scale sources of stress acting on the lithosphere:

1. The orientation of midplate compressive stress field can be explained largely as a function of the applied compressive plate boundary forces (primarily resulting from ridge push and continental collision) and the geometry of the plate boundaries that these forces act on. The effects of forces are felt thousands of kilometers from the actual plate boundary probably due in part to the lateral variations in density/lithospheric structure associated with these boundaries, particularly the ridge push force which results from thickening of oceanic lithosphere with age.

2. Horizontal extensional stresses induced by buoyancy in regions of high elevation locally dominate the midplate compression generated by plate boundary forces.

3. It is difficult to evaluate the role of drag using stress orientation data alone since for most plates, absolute velocity and ridge push torque poles are nearly identical [Richardson, this issue]. However, numerous observations suggest that simple resisting or driving drag (parallel or antiparallel to plate motions) is not very important in controlling the stress field in the uppermost, brittle part of the lithosphere. Lateral stress gradients associated with an order of magnitude variation in stress values across large plates, such as predicted for models in which drag dominates [Richardson, this issue; Richardson and Reding, 1991], are not observed in relative stress magnitude data [Zoback, 1991]. The complex pattern of stresses in Australia and the lack of correlation with absolute plate motion suggest that resistive drag, possibly enhanced beneath an old, cold, fast moving continent, is not a major source of the upper lithospheric stress field. Furthermore, Wiens and Stein [1985] concluded that a general state of compression in old oceanic lithosphere (as inferred from available earthquake focal mechanisms) indicates that the integrated ridge push force dominates drag for all ages. Predictions of stresses related to whole mantle flow inferred from mantle tomography [Bai et al., this issue], while generally producing midplate compression, do not match well the broadest scale patterns observed in the stress data [Zoback, 1991].

\section{Inferring Crustal Stress Magnitudes From STRESS Rotations}

The WSM data base offers the possibility to infer stress magnitudes using local stress rotations (relative to "regional" first-order stress orientations) resulting from stresses caused by specific geologic and tectonic features. The amount of rotation constrains the magnitude of local stresses relative to regional stress differences as has been discussed previously by Sonder [1990]. As described above, first-order patterns of stress in the lithosphere are generally correlatable with plate-driving forces and have extremely large lateral extents, of the order of $50+$ times the thickness of the upper, brittle part of the lithosphere (approximately $20 \mathrm{~km}$ ). Second-order sources considered here are also tectonic in origin and have length scales up to many times the brittle lithosphere thickness but are not necessarily "plate tectonic" in origin. Three main categories of local sources of stresses within the lithosphere are considered here: lithospheric flexure, localized lateral density contrasts, and lateral strength contrasts. These three sources of stress are described below with estimates of the stress magnitudes associated with these features and an evaluation of their influence on the regional stress field with examples.

The interference of a regional stress field and a superimposed uniaxial local stress field can be evaluated quantitatively and depends on the angle between the regional stress 


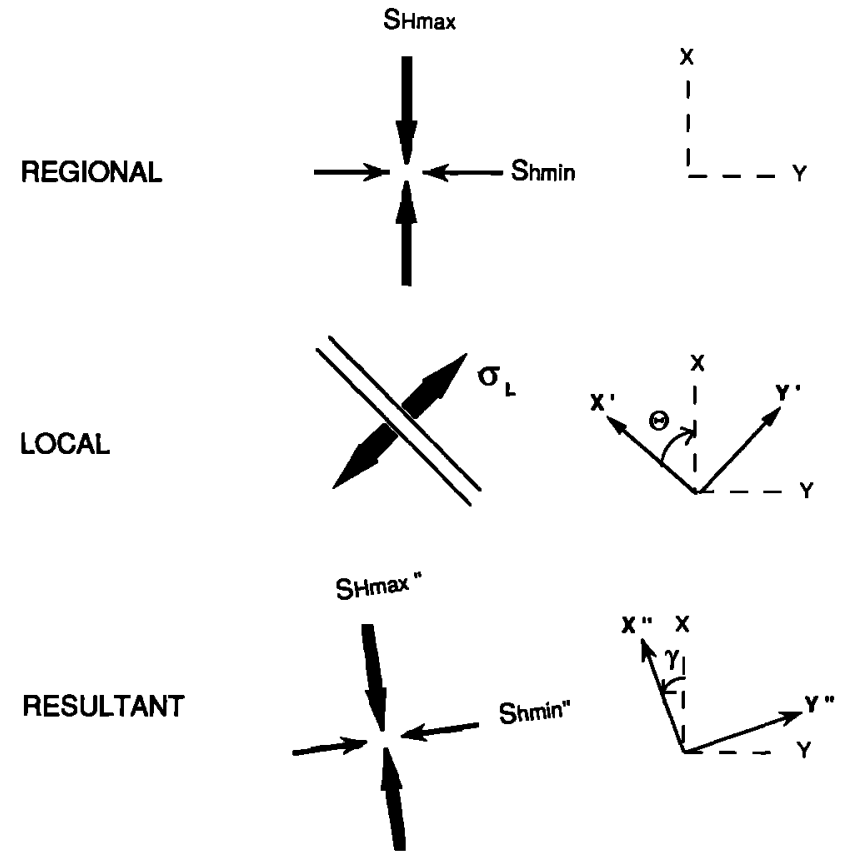

angles measured in direction shown, clockwise angles are positive

Fig. 5. Geometry for evaluating stress rotations due to local sources of stress (modified from Sonder [1990]). $S_{H \max }, S_{H \max }^{\prime \prime}$ and $S_{h \min }, S_{h \min }^{\prime \prime}$ correspond to maximum and minimum horizontal stresses, respectively.

system and the local structure as well as on the the relative magnitudes of the regional and local stress. Following Sonder [1990] and as shown in Figure 5, we define a reference coordinate system $x, y, z$ which coincides with the regional principal stress directions. Assuming that the regional stress field lies in horizontal and vertical planes, the $S_{H \max }$ direction corresponds to the $x$ axis, $S_{h \min }$ coincides with the $y$ axis, and the $z$ axis is vertical downward. The local stress field due to a long structure of arbitrary orientation is defined in a $x^{\prime}, y^{\prime}, z$ coordinate system, where $x^{\prime}$ is the strike of structure and $y^{\prime}$ is the orientation of normal, uniaxial stress. The magnitude of the local horizontal deviatoric stress is $\sigma_{L}: \sigma_{x^{\prime}}=0, \sigma_{y^{\prime}}=\sigma_{L}$ (the local structure is assumed to be long enough that variations in stress in the $x^{\prime}$ direction can be ignored). In the case of local buoyancy forces, a vertical deviatoric stress of equivalent magnitude to the horizontal stress but opposite in sign will also be produced: $\sigma_{z}=-\sigma_{L}$. This vertical stress does not cause horizontal stress rotations but can change the relative stress magnitudes (stress regime), as discussed below. Note that compression is assumed positive in this paper; thus $\sigma_{L}$ is negative for a deviatoric extensional stress and positive for a deviatoric compressive stress (opposite of the convention of Sonder [1990]).

The potential horizontal stress rotations due to a local horizontal deviatoric compression or extension can be evaluated using simple tensor transformation in the horizontal plane. The shear and normal stresses due to the local stress source in the reference coordinate system are given by [e.g., Jaeger and Cook, 1979, p. 14]

$$
\begin{aligned}
\tau_{x y} & =-1 / 2\left(\sigma_{x^{\prime}}-\sigma_{y^{\prime}}\right) \sin 2 \theta \\
& =1 / 2 \sigma_{L} \sin 2 \theta
\end{aligned}
$$

$$
\begin{aligned}
\sigma_{x} & =1 / 2\left(\sigma_{x^{\prime}}+\sigma_{y^{\prime}}\right)+1 / 2\left(\sigma_{x^{\prime}}-\sigma_{y^{\prime}}\right) \cos 2 \theta \\
& =1 / 2 \sigma_{L}(1-\cos 2 \theta) \\
\sigma_{y} & =1 / 2\left(\sigma_{x^{\prime}}+\sigma_{y^{\prime}}\right)-1 / 2\left(\sigma_{x^{\prime}}-\sigma_{y^{\prime}}\right) \cos 2 \theta \\
& =1 / 2 \sigma_{L}(1+\cos 2 \theta)
\end{aligned}
$$

where $\theta$ is the angle between the normal to the uniaxial stress direction (strike of structure) and the regional $S_{H \max }$ direction (angle between $x^{\prime}$ and $x$ ); see Figure 5. The regional and local stresses are then superimposed in the reference regional coordinate system to determine a new resultant stress field:

$$
\begin{aligned}
\tau_{x y} & =1 / 2 \sigma_{L} \sin 2 \theta \\
\sigma_{x} & =S_{H \max }+1 / 2 \sigma_{L}(1-\cos 2 \theta) \\
\sigma_{y} & =S_{h \min }+1 / 2 \sigma_{L}(1+\cos 2 \theta)
\end{aligned}
$$

As the regional reference coordinate system was a principal one, the only contribution to $\tau_{x y}$ is from the local stress. The orientation of the resultant principal stress tensor is given by $x^{\prime \prime}, y^{\prime \prime}, z$. Its orientation relative to the reference, regional stress field is determined from the following expression from Jaeger and Cook [1979, p. 13]:

$$
\tan 2 \gamma=\frac{2 \tau_{x y}}{\sigma_{x}-\sigma_{y}}
$$

Substituting equations (4)-(6) into (7), we can compute the amount of rotation of the regional stress field in the horizontal plane:

$$
\gamma=1 / 2 \tan ^{-1} \frac{\sin 2 \theta}{\left(S_{H \max }-S_{h \min }\right) / \sigma_{L}-\cos 2 \theta}
$$

where $\gamma$ is the angle between the regional $S_{H \max }$ and the resultant local $S_{H \max }$ (angle between $x$ and $x^{\prime \prime}$ ) (the new $S_{h \min }$ orientation is just $\gamma+\pi / 2$ ). This expression is equivalent to that of Sonder [1990], taking into account the difference in nomenclature and sign convention of the local stress.

Equation (8) is plotted in Figure 6, the amount of horizontal stress rotation $(\gamma)$ is given as a function of the orientation of the structure $(\theta)$ for various ratios of the regional horizontal stress difference to the local stress, $\left(S_{H \max }-S_{h \min }\right) / \sigma_{L}$. The sense of rotation depends on the orientation of the structure and whether the local stress is compressive $\left(\left(S_{H \max }-S_{h \min }\right) / \sigma_{L}>0\right)$ or extensional $\left(\left(S_{H \max }-\right.\right.$ $\left.S_{h \min } / \sigma_{L}<0\right)$.

As can be seen in Figure 6, for a negligibly small local stress field, $\left(S_{H_{\max }}-S_{h_{\text {min }}}\right) / \sigma_{L} \approx \infty$, there is no rotation $(\gamma=0)$; alternately, if the local stress field dominates the regional stress field, $\left(S_{H \max }-S_{h \min }\right) / \sigma_{L} \approx 0$, then the stress field rotates into alignment with the local stress field. For a stress ratio $\left(S_{H \max }-S_{h \min }\right) / \sigma_{L}= \pm 2.0$ the maximum possible rotation is only $15^{\circ}$, roughly the detection threshold using stress orientations in the WSM data base. Thus resolvable local rotations imply that the local uniaxial stress must be greater than about half the regional horizontal stress difference. Note also from equation (8), and as shown on Figure 6, that there is a discontinuity in the rotation curves at $\theta= \pm 90^{\circ}$ and $\left(S_{H \max }-S_{h \min }\right) / \sigma_{L}= \pm 1$. For $\mid\left(S_{H \max }-\right.$ 


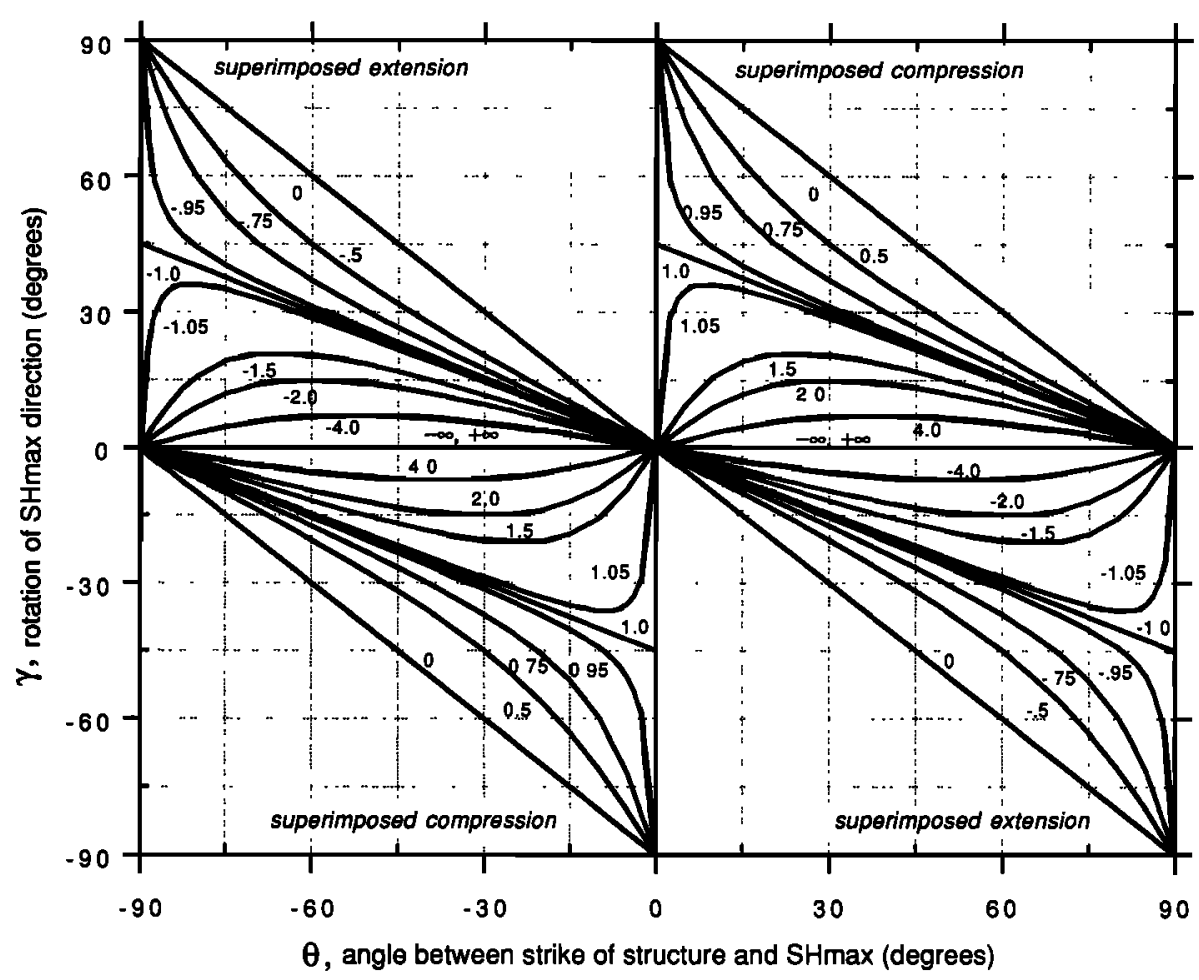

Fig. 6. Stress rotation of regional horizontal stresses $(\gamma)$ as a function of $\theta$, the angle between the strike of the local feature producing the horizontal uniaxial compression or extension and the regional $S_{H \max }$ direction, computed from equation (8). Numbers on curves refer to values of the ratio of regional horizontal stress differences to magnitude of local uniaxial stress, $\left(S_{H \max }-S_{h \min }\right) / \sigma_{L}$; positive values indicate superimposed uniaxial compression and negative values indicate superimposed uniaxial extension.

$\left.S_{h \min }\right) / \sigma_{L} \mid>1.0$ there is no rotation, only a change in the regional principal stress values, whereas for all stress ratios $\left|\left(S_{H \max }-S_{h \min }\right) / \sigma_{L}\right|<1.0$ there is complete $90^{\circ}$ rotation. For $\theta= \pm 90^{\circ}$ the rotation is not defined because both horizontal stresses are equal when $\left(S_{H \max }-S_{h \min }\right) / \sigma_{L}=$ \pm 1 .

Equation (8) and Figure 6 are valid for all regional stress states. Because the amount of rotation is inversely proportional to the difference of the two horizontal stress magnitudes, the larger the horizontal stress difference, the smaller the rotation (all other factors being equal). In a strike-slip faulting stress regime where $S_{1}=S_{H \max }$ and $S_{3}=S_{h \min }$, one can expect the largest horizontal stress differences $\left(S_{H \max }-S_{h \min }\right)=\left(S_{1}-S_{3}\right)$. By contrast, for a regional thrust or normal faulting regime the horizontal stress differences $\left(S_{H \max }-S_{h \min }\right)$ are smaller (equivalent to $\left(S_{1}-S_{2}\right)$ or $\left(S_{2}-S_{3}\right)$, respectively); therefore the expected rotation in a thrust or normal faulting stress regime due to local superimposed stress would be larger than that in the strikeslip regime. For the case in which $S_{2}$ lies exactly halfway between $S_{1}$ and $S_{3}$ in magnitude $\left(\phi=0.5\right.$, where $\phi=\left(S_{2}-\right.$ $\left.S_{3}\right) /\left(S_{1}-S_{3}\right)$, the so-called "stress deviator" [Angelier, 1979]), the corresponding rotation in a thrust or normal regime due to an equivalent local stress would be twice that in a strike-slip faulting regime.

As noted above, in addition to rotating the principal stress field, the superposition of the local stress also influences the relative magnitudes of the stresses and can result in a change in the magnitude of one or both of the horizontal stress magnitudes relative to the vertical stress (hence a change in relative stress magnitudes or stress regime). Sonder [1990] considered deviatoric stresses (normalized with respect to the vertical stress) and computed the resultant stress regime for a superimposed local buoyancy force with both a horizontal $\left(\sigma_{L}\right)$ and vertical $\left(-\sigma_{L}\right)$ component. The resultant stress regime is a function of both the ratio of the magnitude of the regional to local stress and the strike of the local structure relative to the regional stress field. Her calculations for a strike-slip reference stress state are replotted in Figure 7 as a function of the stress ratio used here, $\left(S_{H \max }-\right.$ $\left.S_{h \min }\right) / \sigma_{L}$. It is clear that a strike-slip reference state will be

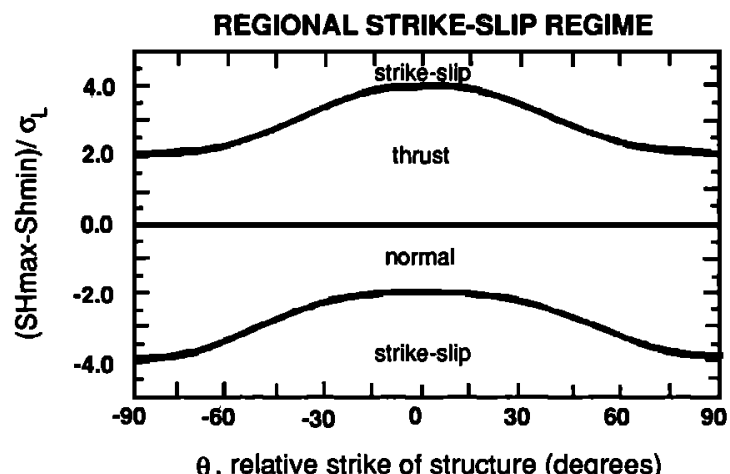

Fig. 7. Expected "local" stress regime for a buoyancy stress (horizontal stress component $\sigma_{L}$, vertical stress component $-\sigma_{L}$ ) superimposed on a regional strike-slip regime. Stress regime is a function of the angle between the local structure $\theta$ and the strike of $S_{H \max }$ regionally and the stress ratio $\left(S_{H \max }-S_{h \min }\right) / \sigma_{L}$. (Superimposed extension corresponds to negative values of ( $S_{H \max }-$ $\left.\left.S_{h \min }\right) / \sigma_{L}.\right)$ 
converted locally to a normal or thrust faulting stress regime when $\left|\left(S_{H \max }-S_{h \min }\right) / \sigma_{L}\right|<2.0-4.0$ (depending on the strike of the local structure). Thus recognizable local stress rotations may often be accompanied by local changes in stress regime, as has apparently occurred in east Africa (see below).

\section{Second-Order Stress Patterns AND Possible Sources}

\section{Flexural Stresses}

Loads on or within an elastic lithosphere cause deflection and induce flexural stresses which can be quite large (several hundred megapascals) and can perturb the regional stress field with wavelengths as much as $1000 \mathrm{~km}$ (depending on the lateral extent of the load) [e.g., McNutt and Menard, 1982]. Some potential sources of flexural stress influencing the regional stress field include sediment loading, particularly along continental margins; glacial rebound; seamount loading; and the upwarping of oceanic lithosphere oceanward of the trench, the "outer arc bulge" [Hanks, 1971; Chapple and Forsyth, 1979]. The final two examples occur in oceanic lithosphere and have been analyzed extensively theoretically and using bathymetry data. These examples of superimposed flexural stresses can not presently be used, however, to evaluate stress magnitudes quantitatively, as we have only very limited information on regional stress orientations in the adjacent oceanic crust.

Sediment loading on continental margins. A major source of stress at passive continental margins is the sediment load, often more than $10 \mathrm{~km}$ thick [Walcott, 1972 ; Turcotte et al., 1977; Cloetingh et al., 1982]. S. Stein et al. [1989] evaluated the sources of stress acting on passive continental margins and concluded that the flexural stress due to sediment loading should be the dominant effect. Their calculations of sediment-loading stresses for a variety of viscoelastic lithosphere models indicate margin-normal extensional stresses on the loaded continental shelf and margin-normal compression in the adjacent oceanic lithosphere with corresponding stress magnitudes of the order of 100 $\mathrm{MPa}$. These stress magnitudes are roughly an order of magnitude greater than the magnitudes of other stresses that they considered which act along the margins: stresses due to plate-driving forces (ridge push or basal drag), spreading stress due to the lateral density contrast between oceanic and continental crust (see following section), and effects of glacial rebound (see below). S. Stein et al. [1989] point out, however, that there is considerable uncertainty as to how much of the total sediment load to consider. Specifically, how much of that load has been relaxed with time? They also note that there is no clear case that passive margin earthquakes are preferentially associated with the most heavily sedimented margins.

Breakout data are now available from the continental shelves of a number of passive margins: eastern North America; McKenzie delta, NW Canada; eastern China; Australia; and India. If the models of S. Stein et al. [1989] are correct, the state of stress on the continental shelves should be dominated by the sediment-loading effect, and the $S_{H \max }$ orientations shown on Figure 1 and Plate 1 should tend to parallel the continental slope (indicating an $S_{h \min }$ direction perpendicular to the margin). Continental shelf data density is probably only great enough to evaluate this possibility on the northwestern Australian and eastern North American shelves. On the northwestern Australian shelf, stress orientations inferred from breakouts trend both parallel and perpendicular to the local trend of the continental slope, so extensional stresses normal to the slope (indicated by $S_{H \max }$ parallel to the slope) clearly do not dominate everywhere; also the $S_{H \max }$ direction in the continental of Australia is poorly constrained. However, on the passive margin off the eastern United States where the ENE regional $S_{H \max }$ orientation within the midcontinent is well constrained, the $S_{H \max }$ orientations on the shelf generally do parallel the shelf-slope break (Figure 1). This stress state cannot be simply attributed to local topographic effects of the slope because the wells are deep and many breakouts come from sections of the wells which are much deeper than the topography [Dart and Zoback, 1987].

These rotations of the regional stress field can be used to constrain the relative magnitude of the local margin-related stresses relative to the regional stress field due to far-field plate-driving forces. Probably the most dramatic examples of rotation of the regional stress field can be observed offshore of eastern Canada, where the stress data on the continental shelf suggest an $S_{H \max }$ orientation of about $\mathrm{N} 15^{\circ}-25^{\circ} \mathrm{E}$ in contrast to an approximately $\mathrm{N} 55^{\circ}-65^{\circ} \mathrm{E}$ orientation onshore. The trend of the continental slope in this region is roughly $\mathrm{N} 15^{\circ}-25^{\circ} \mathrm{W}$; thus $\theta=+(75 \text { to } 85)^{\circ}$ and the observed rotation of the stress field is $\gamma=-(35 \text { to } 45)^{\circ}$. As shown in Figure 6, this indicates a $\left(S_{H \max }-S_{h \min }\right) / \sigma_{L}=$ -1.0 .

Regional stress differences can be predicted assuming that maximum stress differences are limited by the frictional strength of the crust, often called Byerlee's law using the frictional coefficients from Byerlee [1978]:

$$
\left(S_{1}-P\right) /\left(S_{3}-P\right)=\left[\left(1+\mu^{2}\right)^{1 / 2}+\mu\right]^{2}
$$

where $S_{1}$ and $S_{3}$ are the maximum and minimum principal stresses, respectively; $P$ is pore pressure; and $\mu$ is the frictional coefficient of the most well-oriented faults [e.g., Sibson, 1974; Brace and Kohlstedt, 1980; Zoback and Healy, 1984]. For a regional thrust faulting stress regime (probably most appropriate for this region based on earthquake focal mechanisms), Byerlee's law (equation (9)) yields $S_{1}-S_{3}$ values of about $200 \mathrm{MPa}$ for $4.5 \mathrm{~km}$ depth (the average breakout depth) for a $\mu=0.65$ and hydrostatic pore pressure. Assuming that $S_{3}$ is equal to the lithostat and $S_{2}$ is midway between $S_{1}$ and $S_{3}(\phi=0.5)$ implies regional horizontal stress differences $\left(S_{H \max }-S_{h \min }\right) \approx 100 \mathrm{MPa}$. Using the $\left(S_{H \max }-S_{h \min }\right) / \sigma_{L}=-1.0$ from the observed rotation, the predicted margin-normal extensional stress are estimated at about $100 \mathrm{MPa}$, consistent with $S$. Stein et al.'s [1989] estimate of order $100 \mathrm{MPa}$ for these stresses.

Glacial rebound stresses. Another obvious source of flexure stress is the rebound of the lithosphere in response to the removal of $10,000-20,000$ years ago of thick $(1-5 \mathrm{~km})$ ice sheets which covered the Fennoscandia and and east central Canada (Laurentide) regions. There is a relatively high level of intraplate seismicity in both the Laurentide and Fennoscandia rebounding regions which has been noted by many workers. In Fennoscandia the intraplate seismicity indicates a complex mixture of dominantly thrust but also strike-slip and normal deformation with no clear and consistent relationship to the rebounding region [Gregersen, this issue; 
Müller et al., this issue]. Analysis of focal mechanism data in the Laurentide region has indicated a local perturbation in relative stress magnitudes unaccompanied by any horizontal rotation of stress axes [Zoback, this issue]. Earthquakes in southeastern Canada appear to be occurring in response to a thrust faulting stress regime, whereas those in the central and eastern United States occur in response to a strike-slip faulting stress regime. While this lateral variation in stress regime or relative stress magnitude is spatially correlated with the southern edge of the Laurentide ice sheet, estimates of rebound-related flexural stresses [ $S$. Stein et al., 1989; Clark, 1982] are at least an order of magnitude too low to explain the observed difference in stress regime computed according to Byerlee's law assuming $\mu=0.65$ and hydrostatic pore pressure [Zoback, this issue].

\section{Lateral Density Contrasts/Buoyancy Forces}

Numerous workers have demonstrated that topography and its compensation at depth can generate sizable stresses capable of influencing the tectonic style [Frank, 1972; Artyushkov, 1973; Fleitout and Froidevaux, 1982; Sonder, 1990]. Density anomalies within or just beneath the lithosphere constitute major sources of stress. The integral of anomalous density times depth (density moment of Fleitout and Froidevaux [1982]) characterizes the ability of density anomalies to influence the stress field and to induce deformation. In general, crustal thickening or lithosphere thinning (negative density anomalies) produces extensional stresses, while crustal thinning or lithospheric thickening (positive density anomalies) produces compressional stresses. In more complex cases the resultant state of stress in a region depends on the density moment integrated over the entire lithosphere. In a collisional orogeny, for example, where both the crust and mantle lid are thickened, the presence of the cold lithospheric root can overcome the extensional forces related to crustal thickening and maintain compression [Fleitout and Froidevaux, 1982].

Regional stress fields globally show numerous examples of stress patterns related to lateral density anomalies, many of which are tied to compensation of topography. This influence is probably most striking in the regions of active extensional tectonism within the largely compressional midplate regions, which are usually areas of high topography: East African rift, Baikal rift, western U.S. Cordillera, high Andes, and the Tibetan plateau. The presence of thin crust in the East African rift, the Baikal rift, and the western U.S. Cordillera indicates that the source of the high elevation is related to a thinned mantle lithosphere and upwelling hot asthenosphere (see references of Zoback and Magee [1991]). In both the Andes [Isacks, 1988] and the Himalayas [Fleitout and Froidevaux, 1982; England and Houseman, 1989] the elevation and extensional tectonism have been attributed both to a thickened crust as well as to a thinned mantle lithosphere. Froidevaux and Isacks [1984] used the geoid anomaly associated with the 4000-m-high Altiplano-Puna plateau of the Andes to compute a buoyancy-related force (per unit length of boundary) of between 4 and $5 \times 10^{12} \mathrm{~N} / \mathrm{m}$. This is comparable to the total ridge push force per unit length of 2-3 $\times 10^{12} \mathrm{~N} / \mathrm{m}$ [Frank, 1972; Lister, 1975; Parsons and Richter, 1980]. Thus buoyancy-related forces clearly are as important in the overall force balance of the plates and the plate-driving forces, and the stress distribution within the plates reflects the overall net force balance. Several specific examples of the effects of buoyancy forces related to lateral variations in lithosphere thickness are given below as well as examples of other possible stress effects related to lateral density variations within the crust.

Example of rotations due to lithospheric thinning: The East African rift. One of the broadest scale stress patterns which can be attributed to effects of lithospheric thinning is the NW directed contemporary extension $\left(S_{H \max }\right.$ oriented $\mathrm{N} 40^{\circ}-50^{\circ} \mathrm{E}$ ) in the east African region [Bosworth et al, this issue]. As described above, new stress data in central and western Africa suggest a midplate compressive (strike-slip) stress regime with an $S_{H \max }$ orientation of approximately $\mathrm{E}-\mathrm{W}\left(\mathrm{N} 100^{\circ} \mathrm{E}\right)$. Gravity data suggest that lithospheric thinning in the East African rift occurs along approximately a N-S axis [Brown and Girdler, 1980] which should produce a local deviatoric extensional stress oriented approximately $\mathrm{E}-\mathrm{W}$. The contemporary $\mathrm{N} 40^{\circ}-50^{\circ} \mathrm{E} S_{H \max }$ direction of the modern stress field within the East African rift can then be use to constrain the ratio of the regional to local stress. According to equation (8) and Figure 6, for $\theta=+80^{\circ}$ and $\gamma=$ $-(50 \text { to } 60)^{\circ}$, the stress ratio $\left(S_{H \max }-S_{h \min }\right) / \sigma_{L}=-0.8$; that is, the local extensional stresses related to buoyancy must be about slightly greater than ( 1.2 times) the regional horizontal stress differences. Referring to Figure 7, it is clear that the local resultant stress regime for $\left(S_{H \max }-S_{h \text { mm }}\right) / \sigma_{L}$ $=-0.8$ and $\theta=+80^{\circ}$ should be extensional.

Stress differences at $8 \mathrm{~km}$ depth (approximately the middle of the uppermost brittle layer) in the regional strike-slip regime can be determining using Byerlee's law (equation (9)). For hydrostatic pore pressure and a $\mu=0.65$ the predicted stress difference for a strike-slip faulting stress regime is $\left(S_{H \max }-S_{h \min }\right)=144 \mathrm{MPa}$, for $\phi=0.5$. The $\left(S_{H \max }-S_{h \min }\right) / \sigma_{L}=-0.8$ determined from the observed rotation thus implies a mean value for the local deviatoric extension in the upper brittle crust of $\sigma_{L}=-180 \mathrm{MPa}$, assuming that Byerlee's law is valid for predicting the regional stress magnitudes.

Sonder [1990] estimated the near-surface buoyancy stress magnitudes for long-wavelength (mantle) density anomalies to be $\sigma_{L}=\Delta \rho g L / 3$, where $\Delta \rho$ is the density contrast and $L$ is the thickness of the anomalous density layer. Gravity and teleseismic data from the East African rift suggest a mean $\Delta \rho=-30 \mathrm{~kg} / \mathrm{m}^{3}$ for anomalous upper mantle over a thickness of $L=170 \mathrm{~km}$ [Achauer, 1992], yielding a $\sigma_{L}$ of the order of $17 \mathrm{MPa}$. This implies a regional $\left(S_{H \max }-S_{h \min }\right)$ value of only $13.6 \mathrm{MPa}$ based on the rotation. The order of magnitude difference in stress magnitudes inferred from a rotation due to a modeled local stress and that calculated by Byerlee's law (with $\phi=0.5$ and hydrostatic pore pressure) demonstrates how little is known about in situ stress magnitudes in the brittle crust at seismogenic depths and points to the potential usefulness of analysis of local stress rotations in constraining these stress magnitudes.

Examples of rotation due to lithospheric thickening: Colorado Plateau and the Western Alps. Because mantle lithosphere is denser (colder) than the surrounding asthenosphere, there is a tendency for a thick cold mantle root to sink and generate compression along its margins. Such a mechanism has been invoked to explain the $90^{\circ}$ rotation of $S_{h \min }$ directions between the Colorado Plateau and the adjacent Basin and Range province in the western United States. Both areas show an extensional state of stress [Wong 
and Humphrey, 1989; Zoback and Zoback, 1989]. Gravity, geoelectric, and seismic evidence, however, suggests the presence of a thicker, colder mantle lid beneath the plateau relative to the Basin and Range [e.g., Thompson and Zoback, 1979]. Thompson and Zoback [1979] suggested that "ridge push" type forces acting on this keel of mantle lid material were responsible for the $90^{\circ}$ rotation of horizontal stresses and for producing compressional tectonism within the Colorado Plateau interior. However, since this initial suggestion, additional stress data have become available for the Colorado Plateau. While the $90^{\circ}$ rotation of $S_{h \min }$ directions is still valid, the stress state in the plateau interior is now known to be extensional [Wong and Humphrey, 1989] rather than compressional as originally suggested by Thompson and Zoback [1979] and Zoback and Zoback [1980]; thus the buoyancy-related compression appears large enough to rotate the horizontal stresses but not to change the stress regime.

Another example of the stress effect due to a thick mantle keel may be the approximately $50^{\circ}$ counterclockwise rotation of $S_{H \max }$ orientations in the Western Alps, a region characterized by approximately E-W compression, in marked contrast to the general pattern of NW compression observed throughout western Europe [Grünthal and Stromeyer, this issue; Müller et al., this issue]. Fleitout and Froidevaux [1982] and Grünthal and Stromeyer [this issue] suggest that the presence of a nearly 200-km-thick, approximately N-S trending lithospheric root beneath this region may be responsible for the observed rotation. In this example, $\theta=-35^{\circ}$ and $\gamma=-50^{\circ}$, indicating a stress ratio $\left(S_{H \max }\right.$ $\left.-S_{h \min }\right) / \sigma_{L}=+0.4$, implying that the local compressional stress must be more than 2.5 times the regional stress differences.

Crustal contrast at ocean/continent boundary. Bott and Dean [1972] suggested that the lateral variation in crustal thickness and density along continental margins should induce margin-normal extension within the continental crust and margin-normal compression in the adjacent oceanic crust. S. Stein et al. [1989] estimate the magnitude of these "crustal spreading" stresses to be $\sim 10 \mathrm{MPa}$. Since the induced stresses on continental margins have the same sign as flexural stresses related to sediment loading, it is difficult to separate these two effects. The crustal spreading stresses may be more concentrated in regions where the continental shelf is narrow and slope is quite steep, such as in northern South America (see Assumpcao [this issue] for a discussion of seismicity along the easternmost coast of Brazil).

Lateral density contrast in crust "rift pillow." Perhaps one of the most convincing examples of a local stress rotation due to lateral density contrasts within the crust occurs within the South American craton in north central Brazil along the northern boundary of the E-W trending Amazonas rift. This Paleozoic rift zone is marked by a rift basin filled with up to $7 \mathrm{~km}$ of gently dipping, shallow water sediments of Ordovician to Permian age and an associated $\sim 100 \mathrm{mGal}$ Bouguer gravity high [Nunn and Aires, 1988]. Nunn and Aires [1988] demonstrate that the observed gravity anomalies can be explained by a steep-sided zone of high density in the lower crust varying from 100 to $200 \mathrm{~km}$ in width. Two moderate-sized midplate thrust earthquakes $\left(m_{b}\right.$ $=5.1$ and 5.5) have occurred along the northern boundary of the rift in the last 30 years. These events are anomalous in that they are deep (21 and $45 \mathrm{~km}$ ) for intraplate seismicity and because they both indicate N-S compression [Assumpcao and Suarez, 1988], which is in sharp contrast to the regional E-W compression direction for much of the South American plate (see Figure 1, Plate 1, and Assumpcao [this issue].

It is hypothesized that the apparent $90^{\circ}$ rotation of $S_{H \max }$ orientation in the vicinity of the rift results from the effects of a dense lower crustal "rift pillow" probably initially formed as a result of mafic magmatic intrusion during rifting and is now frozen into the lower crust. The excess mass is supported by the strength of the now cool lithosphere, inducing deviatoric compression perpendicular to the rift axis.

Richardson and Zoback [1990] presented two-dimensional finite element models of the Amazonas rift constrained by surface geometry, geology, and gravity data. The plane strain models include both lithospheric material which can support elastic stresses and asthenospheric material which cannot support elastic stresses for long times. The modeling results indicate that the rift pillow (density contrast $\Delta \rho=$ $+150 \mathrm{~kg} / \mathrm{m}^{3}$ ) is capable of generating $60-200 \mathrm{MPa}$ of riftnormal (approximately N-S) deviatoric compression within the crust [Richardson and Zoback, 1990]. Model stresses are greatest at midcrustal depths, consistent with the observed depth of the nearby thrust earthquakes.

Note that in Figure 6 because the rift structure is parallel to the regional $S_{H \max }$ direction $\left(\theta=0^{\circ}\right)$ and the observed rotation is about $90^{\circ}\left(\gamma=90^{\circ}\right)$, the only real constraint on $\left(S_{H \max }-S_{h \min }\right) / \sigma_{L}$ is that the ratio must be $>1.0$ (corresponding to the discontinuity in the curves discussed previously). This implies that the regional horizontal stress differences should be $>60-200 \mathrm{MPa}$ based on the results of the finite element modeling of the density structure described above. This value can be compared with predicted regional stress magnitudes computed using Byerlee's law for an inferred regional thrust faulting stress regime with hydrostatic pore pressure and $\mu=0.65$. To explain the observed $90^{\circ}$ local stress rotation, the regional $S_{h \min }$ magnitude must be increased above the regional $S_{H \max }$ value. The maximum stress difference $\left(S_{1}-S_{3}\right)$ predicted by Byerlee's law at 20 $\mathrm{km}$ depth (approximately the depth of one of the two earthquakes) in a thrust regime is quite large $\left(S_{H \max }-S_{v}\right) \approx$ $800 \mathrm{MPa}$; the corresponding horizontal stress differences $\left(S_{H \max }-S_{h \min }\right)$ however, are poorly constrained because of uncertainty as to the relative magnitude of the intermediate stress. For an assumed $\phi=0.5,\left(S_{H \max }-S_{h \min }\right)=400 \mathrm{MPa}$. However, the computed $\sigma_{L} \geq 60-200 \mathrm{MPa}$ may be consistent with the stress magnitude prediction based on Byerlee's law due to the lack of constraint on the regional $\phi$ value. The vertical stress is also somewhat reduced in the upper crust due to the presence of the dense body in the lower crust. The computed reduction in vertical stress above the rift pillow, however, is less than $10 \%$ of the induced horizontal compression (R. Richardson, written communication, 1990) amounting to about $10-20 \mathrm{MPa}$ and probably not really significant at $20 \mathrm{~km}$ depth.

Seismic refraction data indicate the presence of a lower crustal rift pillow ( $P$ wave velocity between 7.2 and 7.5 $\mathrm{km} / \mathrm{s}$, intermediate between normal lower crust and upper mantle velocities) beneath many continental rifts, both modern and ancient [Mooney et al., 1983]. In young, active rifts this dense load is compensated by lithospheric thinning; however, after active rifting has ended (possibly in response to changes in far-field stress state), this dense load remains 
and must be supported by the strength of the lithosphere. The induced rift-normal compression may help explain the often observed correlation between intraplate seismicity and old rift zones [e.g., Johnston, 1989; Johnston and Kantor, 1990; Mitchell et al., 1991]. This rift pillow induced compression may also provide a mechanism to enhance basin inversion (in addition to simple cooling and thickening of the lithosphere).

\section{Lateral Strength Contrasts}

The largest-scale example of the possible influence of a lateral variation in crustal strength is the approximately fault-normal compression observed adjacent to the San Andreas right-lateral strike-slip fault. In this case the strength contrast is presumed to be due to the effect of a fault of low frictional shear strength embedded in a frictionally strong crust. $S_{H \max }$ directions in a 100 - to $125-\mathrm{km}$-wide zone on either side of the San Andreas fault are typically oriented $70^{\circ}-85^{\circ}$ to the local trend of the fault [Mount and Suppe, 1987; Zoback et al., 1987; Zoback, 1991; Mount and Suppe, this issue] rather than the expected $30^{\circ}-45^{\circ}$. These stress data are consistent with geologic evidence of young $(<4$ m.y.) folding and reverse faulting with axes and reverse fault trends oriented subparallel to the fault. Thus, because of the presumed low shear strength of the San Andreas (inferred independently from heat flow data [e.g., Lachenbruch and Sass, 1980]) the regional stress field appears to have rotated approximately $50^{\circ}$ so that the fault becomes nearly a principal stress plane, thereby minimizing the shear stress on that plane. Assuming a frictional strength based on Byerlee's law in the crust surrounding the fault, Zoback et al. [1987] used the observed $50^{\circ}-60^{\circ}$ stress rotation in the zone adjacent to the fault to limit the shear strength of the San Andreas to 5-20 MPa, a value consistent with the maximum shear stress allowable by heat flow constraints.

This phenomenon does not appear limited to the San Andreas fault in central California. Zoback [1991] argues that the extension observed in the Gulf of California and Salton Sea/Imperial Valley region is also due to the low strength of the plate boundary. Mount and Suppe [this issue] document fault-normal compression adjacent to the Great Sumatran right-lateral strike-slip fault. Both Mount and Suppe [this issue] and Ben Avraham and Zoback [1992] describe evidence of contemporary fault-normal extension and compression along a number of transform plate boundaries.

\section{Crustal Inhomogeneities and the Stress Field}

The average value of stress induced in the lithosphere by the plate-driving forces probably depends primarily on the thickness of the lithosphere carrying the load [e.g., Kusznir and Bott, 1977]. This results in lower mean stresses in thick, cold "cratonic" lithosphere. The significance of this stress amplification (or deamplification) effect may be viewed, most simply, in terms of the influence of an inhomogeneous, nonuniform (e.g., spatially varying elastic properties) lithosphere (exactly the model which most geologists and geophysicists accept) on the state of stress in the lithosphere. If the mean magnitude of stress in the lithosphere derived from plate-driving forces is lower, for example, in shield areas, then local effects could be expected to dominate. The large scatter of data in Australia may be an example of such an effect. Many shield regions are rather poorly sampled in terms of stress orientations; however, the southeast margin of the Canadian shield is well sampled, and the stress directions are rather consistent.

Major Precambrian boundaries and sutures, where sampled, seem to have little effect on the regional stress orientations. Gregersen [this issue] detected no effects or deviations of stress orientations in the Fennoscandia region associated with known geologic boundaries, such as edge of the Precambrian Baltic shield. Similarly, stress orientations in the eastern United States do not seem perturbed by the boundary of the Grenville front, a major NE trending suture trending approximately from Missouri to New York.

Stress data also demonstrate that at least some major Proterozoic orogenic belts do not significantly perturb the regional stress field. Perhaps the best example is the NE trending Paleozoic Appalachian belt in the eastern United States. This major compressional mountain belt formed as a result of NW compression; however, contemporary $S_{H \max }$ orientations trend ENE along and across the chain, consistent with the midplate North American stress orientation. Clearly "residual stress" related to this orogenic belt has no influence on the modern stress field. In fact, this consistency of modern ENE $S_{H \max }$ orientation is maintained in detail in eastern New York and Pennsylvania through a region where the Appalachian orogenic belt makes a $40^{\circ}$ bend in strike [Evans, 1989]. Similarily, Müller et al. [this issue] note only local perturbations to the western Europe stress directions related to the Tertiary Alpine belt. In the westernmost and southwesternmost portions of the Alps, $S_{H \max }$ directions are normal to the Alpine front and form an approximately radial pattern consistent with the trends of Pliocene folds. This radial pattern has been interpreted as the result of crustal indentation related to the continued convergence of Europe and Africa [Pavoni, 1961], or alternately, as mentioned above, the E-W compression in the Western Alps may be related to the stress effects of a deep cold mantle lithosphere root extending to $200 \mathrm{~km}$ depth beneath the region [Fleitout and Froidevaux, 1982; Grünthal and Stromeyer, this issue].

Thus the stress field with its regional uniformity within an enormously complex, inhomogeneous, and anisotropic lithosphere appears to be a fundamental observation. This observation is very strong evidence for a lithospheric stress state strongly dependent on the contemporary forces applied along the boundaries of the plates. Residual stresses from past orogenic events to not appear to contribute in any substantial way to the modern stress field.

\section{Conclusions}

Over 4400 reliable data on tectonic stress orientations in the upper brittle part of the lithosphere have been compiled globally. Consistency between shallow, near-surface stress orientations and those inferred at depth from earthquake focal mechanisms indicates a relatively uniform stress field throughout the brittle part of the crust. The data also indicate broad regions (up to $5000 \mathrm{~km}$ long on a side) of uniform stress orientation and relative magnitude within the interior portions of many plates. The orientation and general compressional nature of many of these "first-order" stress patterns indicate that these midplate stress fields are largely the result of compressional plate-driving forces, primarily 
those of ridge push and continental collision, acting on plate geometry. The far-reaching effects of these forces, particularly ridge push, are probably related to the broad-scale lateral density anomalies associated the plate boundaries. The role of slab pull forces related to subduction zones is more difficult to evaluate because there are few stress data in the oceans. However, compressional deformation observed for all focal mechanisms in old oceans suggests that midplate compression dominates any extensional slab pull forces [Wiens and Stein, 1985].

The influence of drag on the midplate stress field cannot be evaluated using orientations alone since the ridge push torque poles are very similar to the absolute motion poles for most plates [Richardson, this issue]. However, large lateral stress gradients across plates predicted for models dominated by drag forces [e.g., Richardson et al., 1979; Richardson and Reding, 1991] are not observed [Zoback, 1991]. In addition, the large scatter of stress orientations in Australia and the poor correlation between $S_{H \max }$ and absolute motion directions particularly in the southeastern and southwestern parts of this old, cold, and fast moving continent suggest that simple driving or resisting drag is not a dominant force affecting the intraplate stress field. More complex models of drag related to convection patterns inferred from mantle mass anomalies are just now becoming possible [see Bai et al., this issue]. However, because plate tectonics represents the uppermost part of the Earth's convection system, the intraplate stress field ultimately has its origin in convection system in the Earth's mantle.

Recognition of the broad-scale "first-order" stress patterns derived primarily from plate driving forces allows identification of local stress perturbations related to known geologic or tectonic features. Buoyancy forces related to crustal thickening and/or lithospheric thinning are probably responsible for some of the largest of these perturbations. Intraplate areas of active extension are generally associated with regions of high topography: western U.S. Cordillera, high Andes, Tibetan plateau, and also the western Indian Ocean plateau (however, extension here has also been explained in terms of slab pull-induced extension [Stein et al., 1987] and thermoelastic stresses [Bergman, 1986; Bergman et al., 1984]. In these regions, buoyancy-derived extensional stresses dominate the intraplate compressional stress field and indicate that buoyancy forces derived from lateral variations in crust and upper mantle structure supporting topography can be on the same order of magnitude as plate-driving forces, a conclusion reached independently by direct calculation of these forces [e.g., England and Molnar, 1991].

Other sources of local perturbations or second-order stress fields include flexural stresses, smaller-scale lateral density contrasts, and lateral variations in crustal strength. Often these local features result in a rotation of the horizontal stresses. A two-dimensional analysis of the amount of rotation of regional horizontal stress orientations due to a superimposed local horizontal uniaxial stress constrains the ratio of the horizontal regional stress differences to the local uniaxial stress. For a detectable rotation of $15^{\circ}$, the local horizontal uniaxial stress $\left(\sigma_{L}\right)$ must be at least half the magnitude of the regional horizontal stress differences ( $\sigma_{L}=$ $\left.0.5\left(S_{H \max }-S_{h \min }\right)\right)$. In thrust or normal faulting stress regimes, the horizontal component of the regional stress differences would be less than that in the strike-slip faulting regime. (Assuming a $\phi=0.5$ in which $S_{2}$ lies halfway between $S_{1}$ and $S_{3}$, the horizontal component of the regional shear stress for thrust or normal regimes would be $1 / 2$ that in a strike-slip faulting regime.) Thus, in regional normal and thrust regimes, larger rotations (relative to a regional strike-slip regime) are possible for similar values of the local stresses.

Apparent examples of local rotations of $S_{H \max }$ orientations include a $75^{\circ}-85^{\circ}$ rotation on the northeastern Canadian continental shelf possibly related to margin-normal extension derived from sediment-loading flexural stresses, a $50^{\circ}-$ $60^{\circ}$ rotation with the East African rift relative to western Africa due to extensional buoyancy forces associated with lithospheric thinning, a $50^{\circ}$ rotation in the Western Alps possibly related to the presence of a dense lithospheric root, and an approximately $90^{\circ}$ rotation along the northern margin of the Paleozoic Amazonas rift in central Brazil. In this final example, the rotation is hypothesized to result from deviatoric compression oriented normal to the rift axis due to local lithospheric support of a dense mass in the lower crust, a so-called "rift pillow." This rift-normal compression due to support of the rift pillow may be a common feature of the old rift zones in intraplate regions and may provide a physical explanation for the often noted correlation between intraplate seismicity and old rift zones [e.g., Johnston, 1989; Johnston and Kantor, 1990].

Estimates of regional stress differences determined from modeling the source of local stress rotations can be compared with regional stress magnitudes computed using Byerlee's law to test the applicability of this law to the upper brittle lithosphere. The examples of superimposed local stresses analyzed here (extensional flexural stresses on the NE Canadian margin, buoyancy-related stresses in the East African and Amazonas rifts) are too few to provide a definitive evaluation of the direct applicability of Byerlee's law, particularly in view of uncertainties in pore pressure and relative magnitudes of the intermediate principal stresses. Nonetheless, the observed rotations all indicate that the magnitude of the local deviatoric stresses must be 1.0 to at least 2.5 times the first-order regional horizontal stress differences in the crust which are believed to be derived primarily from plate-driving forces. These few examples do demonstrate that careful evaluation of such local rotations is potentially a very useful technique for constraining the magnitude of deviatoric stresses in the upper brittle part of the lithosphere, particularly at depths below which direct measurements of stress magnitude may be possible.

Acknowledgments. This project would not have been possible without the hard work and willing cooperation of a large number of individuals; all of the scientists listed in Table 1 devoted a lot of time to the relatively thankless task of compiling their own data and that of others in a common format and of checking and rechecking that data. Two individuals merit special mention: Birgit Müller (Karlsruhe University) for her indefatigable efforts to unite Europe, at least within a stress data base framework and Marian Magee (U.S. Geological Survey and Stanford University) both for her constant vigilance over the data base and her careful interpretation of the many varied and creative formats in which data were submitted as well as for software development for producing the stress maps. Special thanks to Mara Schiltz, Harold Gurrola, and Linda Shijo, who have assisted in data compilation, map software development, and data base management over the years. Many of the ideas presented here, as well as the conceptual approach to evaluation of tectonic stress indicators, have evolved over years of collaboration 
with Mark Zoback. Discussions with Art McGarr and Randy Richardson have also increased my understanding of stress in the Earth; any shortcomings in this understanding are my own, however. Their reviews of this paper led to a number of substantiative improvements. I thank Bob Simpson for providing critical reins on wild ideas and also for providing the initial software and continued assistance for the map plotting. And finally, I am indebted to Karl Fuchs, who, as president of the International Lithosphere Program from 1985 to 1990 , conceived this project, promoted it globally, and continues to provide ideas as well as impetus and opportunities for third world countries to participate. The U.S. Nuclear Regulatory Commission provided financial support for much of the breakout analysis and interpretation in the United States. Funds for travel and workshops were provided by the International Lithosphere Program and the special research program at Karlsruhe University SFB 108, "Stress and Stress Release in the Lithosphere" (of the Deutsche Forschungsgemeinschaft).

\section{REFERENCES}

Achauer, U., A combined study of delay-time tomography analysis and gravity modeling for the Kenya rift, Tectonophysics, in press, 1992.

Adams, J., Canadian crustal stress database-A compilation to 1987, Geol. Surv. Can. Open File Rep., 622, 130 pp., 1987.

Adams, J., Crustal stresses in eastern Canada, in Earthquakes at North Atlantic Passive Margins: Neotectonics and Postglacial Rebound, edited by S. Gregersen and P. W. Basham, pp. 355-370, Kluwer Academic, Boston, Mass., 1989.

Adams, J., and J. S. Bell, Crustal stresses in Canada, in The Geology of North America, Decade Map Vol. 1, Neotectonics of North America, edited by B. Slemmons et al., pp. 367-386, Geological Society of America, Boulder, Colo., 1991.

Anderson, E. M., The Dynamics of Faulting and Dyke Formation With Applications to Britain, $206 \mathrm{pp}$., Oliver and Boyd, Edinburgh, 1951.

Anderson, H., Comparison of centroid-moment tensor and first motion solutions for western Mediterranean earthquakes, Phys. Earth Planet. Inter., 52, 1-7, 1988.

Angelier, J., Determination of the mean principal directions of stresses for a given fault population, Tectonophysics, 56, T17T26, 1979.

Angelier, J., Tectonic analysis of fault slip data sets, J. Geophys. Res., 89, 5835-5848, 1984.

Artyushkov, E. V., Stresses in the lithosphere caused by crustal thickness inhomogeneities, J. Geophys. Res., 78, 7675-7708, 1973.

Assumpcao, M., The regional intraplate stress field in South America, J. Geophys. Res., this issue.

Assumpcao, M., and G. Suarez, Source mechanisms of moderatesize earthquakes and stress orientation in mid-plate South America, Geophys. J., 92, 253-267, 1988.

Babcock, E. A., Measurement of subsurface fractures from dipmeter logs, AAPG Bull., 62, 1111-1126, 1978.

Bai, W., C. Vigny, Y. Ricard, and C. Froidevaux, On the origin of deviatoric stresses in the lithosphere, J. Geophys. Res., this issue.

Barton, C. A., M. D. Zoback, and K. L. Burns, In-situ stress orientation and magnitude at the Fenton Hill geothermal site, New Mexico, determined from wellbore breakouts, Geophys. Res. Lett., 15, 467-470, 1988.

Becker, A., and S. Paladini, In-situ spannungen in nord- und mitteleuropa, in Schriftenreihe Angewandte Geologie Karlsruhe, vol. 10, edited by K. Czurda and H. Hoetzl, pp. 1-63, Karlsruhe, Germany, 1990.

Behrendt, J. C., and A. Cooper, Evidence of rapid Cenozoic uplift of the shoulder escarpment of the Cenozoic west Antarctic rift system and a speculation on possible climate forcing, Geology, 19, 315-319, 1991

Behrendt, J. C., W. E. LeMasurier, A. K. Cooper, F. Tessensohn, A. Trehu, and D. Damaske, Geophysical studies of the west Antarctic rift system, Tectonics, 10, 1257-1273, 1991.

Bell, J. S., Investigating stress regimes in sedimentary basins using information from oil industry wireline logs and drilling records, Geol. Soc. Spec. Publ. London, 48, 305-325, 1990.

Bell, J. S., and D. I. Gough, Northeast-southwest compressive stress in Alberta: Evidence from oil wells, Earth Planet. Sci. Lett., 45, 475-482, 1979.
Ben-Avraham, Z., and M. D. Zoback, Transform normal extension along weak plate boundaries: an alternative to the pull-apart model, Geology, in press, 1992.

Bergman, E. A., Intraplate earthquakes and the state of stress in oceanic lithosphere, Tectonophysics, 132, 1-35, 1986.

Bergman, E. A., J. L. Nabelek, and S. C. Solomon, An extensive region of off ridge normal-faulting earthquakes in the southern Indian Ocean, J. Geophys. Res., 89, 2425-2443, 1984.

Bonilla, M. G., and J. M. Buchanan, Interim report on world-wide historic surface faulting, U.S. Geol. Surv. Open File Rep., 32 pp., 1970.

Bosworth, W., M. R. Strecker, and P. M. Blisniuk, Integration of East African paleostress and present-day stress data: Implications for continental stress field dynamics, J. Geophys. Res., this issue.

Bott, M. H. P., and D. S. Dean, Stress systems at young continental margins, Nature Phys. Sci., 235, 23-25, 1972.

Brace, W. F., and D. L. Kohistedt, Limits on lithospheric stress imposed by laboratory experiments, J. Geophys. Res., 85, 6248$6252,1980$.

Bratt, S. R., E. A. Bergman, and S. C. Solomon, Thermoelastic stress: How important as a cause of earthquakes in young oceanic lithosphere?, J. Geophys. Res., 90, 10,249-10,260, 1985.

Brereton, N. R., and C. J. Evans, Rock stress orientations in the United Kingdom from borehole breakouts, Rep. $R G 87 / 14,36$ pp., Br. Geol. Surv., Keyworth, England, 1987.

Brown, C., and R. W. Girdler, Interpretation of African gravity and its implication for the breakup of the continents, $J$. Geophys. Res., 85, 6443-6445, 1980.

Brudy, M., Modellierung des Europaeischen Spannugsfelds unter besonderer Berucksichtigung neuer Daten aus Nordwesteuropa, diploma thesis, Univ. Karlsruhe, Germany, 1990.

Burchfiel, C. B., and L. H. Royden, North-south extension within the convergent Himalayan region, Geology, 13, 679-682, 1985.

Byerlee, J. D., Friction of rock, Pure Appl. Geophys., 116, 615-626, 1978.

Carey, E., Computation of principal stress axes associated with observed motions on fault planes, Rev. Geol. Dyn. Geogr. Phys., $21,57-66,1979$.

Carey, E., and B. Brunier, Analyse theorique et numerique d'un modele mechanique elementaire applique a l'etude d'une population de failles, C. R. Hebd. Seances Acad. Sci., 279, 891-894, 1974.

Chapple, W. M., and D. Forsyth, Earthquakes and bending of plates at trenches, J. Geophys. Res., 84, 6729-6749, 1979.

Chapple, W. M., and T. E. Tullis, Evaluation of the forces that drive the plates, J. Geophys. Res., 82, 1967-1984, 1977.

Chase, C. G., Asthenospheric counterflow: A kinematic model, Geophys. J. R. Astron. Soc., 56, 1-18, 1979.

Choy, G. L., and J. R. Bowman, Rupture process of a multiple main shock sequence: Analysis of teleseismic, local, and field observations of the Tennant Creek, Australia, Earthquakes of January 22, 1988, J. Geophys. Res., 95, 6867-6882, 1990.

Clark, J. A., Glacial loading: A cause of natural fracturing and a control of the present stress state in regions of high Devonian shale gas, paper SPE 10798, presented at Unconventional Gas Recovery Symposium, Soc. of Pet. Eng., Pittsburgh, Pa., May 16-18, 1982.

Cloetingh, S. A. P. L., and M. J. R. Wortel, Regional stress field of the Indian plate, Geophys. Res. Lett., 12, 77-80, 1985.

Cloetingh, S. A. P. L., and M. J. R. Wortel, Stress in the IndoAustralian plate, Tectonophysics, 132, 49-67, 1986.

Cloetingh, S. A. P. L., M. J. R. Wortel, and N. J. Vlaar, State of stress at passive margins and initiation of subduction zones, Nature, 297, 139-142, 1982.

Cornet, F. H., and D. Burlet, Stress field determinations in France by hydraulic tests in boreholes, J. Geophys. Res., this issue.

Cornet, F. H., and B. Valette, In situ stress determination from hydraulic injection test data, J. Geophys. Res., 98, 11,527-11,537, 1984

Cox, J. W., The high resolution dipmeter reveals dip-related borehole and formation characteristics, Trans. SP WLA, Annu. Logging Symp., 1lth, 1-25, 1970.

Dart, R., South-central United States well-bore breakout data catalog, U.S. Geol. Surv. Open File Rep., 87-405, 95 pp., 1987.

Dart, R., and M. L. Zoback, Principal stress orientations on the Atlantic continental shelf inferred from the orientations of bore- 
hole elongations, U.S. Geol. Surv. Open File Rep., 87-283, 43 pp., 1987.

Delaney, P. T., D. D. Pollard, J. I. Ziony, and E. H. McKee, Field relations between dikes and joints: Emplacement processes and paleostress analysis, J. Geophys. Res., 91, 4920-4938, 1986.

Dziewonski, A. M., and J. H. Woodhouse, An experiment in systematic study of global seismicity: Centroid-moment tensor solutions for 201 moderate to large earthquakes of $1981, J$. Geophys. Res., 88, 3247-3271, 1983.

Engelder, T., Stress Regimes in the Lithosphere, Princeton University Press, Princeton, N. J., in press, 1992.

Engelder, T., and M. L. Sbar, Near-surface in situ stress: Introduction, J. Geophys. Res., 89, 9321-9322, 1984.

England, P., and G. Houseman, Extension during continental convergence, with application to the Tibetan Plateau, J. Geophys. Res., 94, 17,561-17,579, 1989.

England, P., and P. Molnar, Inferences of deviatoric stress in actively deforming belts from simple physical models, Proc. $R$. Soc. London, Ser. A, 337, 151-164, 1991.

Estabrook, C. H., and K. H. Jacob, Stress indicators in Alaska, in The Geology of North America, Decade Map vol. 1, Neotectonics of North America, edited by B. Slemmons et al., pp. 387-400, Geological Society of America, Boulder, Colo., 1991.

Evans, K. F., Appalachian stress study, 3, Regional scale stress variations and their relation to structure and contemporary tectonics, J. Geophys. Res., 94, 17,619-17,645, 1989.

Fleitout, L., and C. Froidevaux, Tectonics and topography for a lithosphere containing density heterogeneities, Tectonics, 1, 21$56,1982$.

Forsyth, D. W., and S. Uyeda, On the relative importance of the driving forces of plate motion, Geophys. J. R. Astron. Soc., 43, 163-200, 1975.

Frank, F. C., Plate tectonics, the analogy with glacier flow and isostasy, in Flow and Fracture of Rocks, Geophys. Monogr. Ser., vol. 16, pp.285-292, AGU, Washington, D. C., 1972.

Froidevaux, C., and B. L. Isacks, The mechanical state of stress of the Altiplano-Puna segment of the Andes, Earth Planet. Sci. Lett., 71, 305-314, 1984.

Gough, D. I., Mantle upflow under North American and plate dynamics, Nature, 31I, 428-433, 1984.

Gough, D. I., and R. S. Bell, Stress orientations from borehole wall fractures with examples from Colorado, east Texas, and northern Canada, Can. J. Earth Sci., 19, 1358-1370, 1982.

Govers, R., M. J. R. Wortel, S. A. P. L. Cloetingh, and C. A. Stein, Stress magnitude estimates from earthquakes in oceanic plate interiors, J. Geophys. Res., this issue.

Gowd, T. N., S. V. Srirama Rao, and V. K. Gaur, Tectonic stress field of the Indian subcontinent, J. Geophys. Res., this issue.

Gregersen, S., Crustal stress regime in Fennoscandia from focal mechanisms, J. Geophys. Res., this issue.

Grünthal, G., and D. Stromeyer, The recent crustal stress field in central Europe: Trajectories and finite element modeling, $J$. Geophys. Res., this issue.

Hager, B. H., and R. J. O'Connell, Kinematic models of large-scale flow in the Earth's mantle, J. Geophys. Res., 84, 1031-1048, 1979.

Haimson, B. C., Near-surface and deep hydrofracturing stress measurements in the Waterloo Quartzite, Proc. U.S. Symp. Rock Mech., 19th, 345-361, 1978.

Haimson, B. C., Stress measurements in the Wasatch hinterland complement existing tectonic and seismic stress, Eos Trans. $A G U, 65,1118-1119,1984$.

Haimson, B. C., and C. Fairhurst, In situ stress determination at great depth by means of hydraulic fracturing, Proc. U.S. Symp. Rock Mech., 11th, 559-584, 1970.

Hancock, P. L., Determining contemporary stress directions from neotectonic joint systems, Trans. R. Soc. London, Ser. A, 337, 29-40, 1991.

Hancock, P. L., and T. Engelder, Neotectonic joints, Geol. Soc. Am. Bull., 101, 1197-1208, 1989.

Hanks, T. H., The Kuril Trench-Hokkaido Rise system: Large shallow earthquakes and simple models of deformation, Geophys. J. R. Astron. Soc., 23, 173-189, 1971.

Hiller, R., Australia-Banda arc collision and in situ stress in the Vulcan suh-basin (Timor Sea) as revealed by borehole breakout data, Exp. Geophys., 22, 189-194, 1991.
Isacks, B. L., Uplift of the central Andean plateau and bending of the Bolivian orocline, J. Geophys. Res., 93, 3211-3231, 1988.

Jaeger, J. C., and N. G. W. Cook, Fundamentals of Rock Mechanics, 3rd ed., 593 pp., Chapman and Hall, New York, 1979.

Johnston, A. C., Suppression of earthquakes by large continental ice sheets, Nature, 330, 467-469, 1987.

Johnston, A., Seismicity of 'stable continental interiors', in Earthquakes at North Atlantic Passive Margins: Neotectonics and Postglacial Rebound, edited by S. Gregersen and P. W. Basham, pp. 299-327, Kluwer Academic, Boston, Mass., 1989.

Johnston, A., and L. R. Kantor, Earthquakes in stable continental crust, Sci. Am., 262, 68-75, 1990.

Kamoun, Y., and M. Hfaiedh, Neotectonics of Tunisia: A synthesis, paper presented at Second EGT Workshop, Eur. Sci. Found., Venice, Feb. 7-9, 1985.

Klein, R., and M. Barr, Regional state of stress in western Europe, in Proceedings of International Symposium on Rock Stress and Rock Stress Measurements, edited by O. Stephansson, pp. 33-45, Centek, Lules, Sweden, 1987.

Kusznir, N. J., and M. H. P. Bott, Stress concentration in the upper lithosphere caused by underlying visco-elastic creep, Tectonophysics, 43, 247-256, 1977.

Lachenbruch, A. H., and J. H. Sass, Heat flow and energetics of the San Andreas fault zone, J. Geophys. Res., 85, 6185-6223, 1980.

Lister, C. R. B., Gravitational drive on oceanic plates caused by thermal contraction, Nature, 257, 663-665, 1975.

McGarr, A., and N. C. Gay, State of stress in the Earth's crust, Annu. Rev. Earth Planet. Sci., 6, 558-562, 1978.

McKenzie, D. P., The relation between fault plane solutions for earthquakes and the directions of the principal stresses, Bull. Seismol. Soc. Am., 59, 591-601, 1969.

McNutt, M. K., and H. W. Menard, Constraints on yield strength in the oceanic lithosphere derived from observations of flexure, Geophys. J. R. Astron. Soc., 71, 363-394, 1982.

Meijer, P. T., and M. J. R. Wortel, The dynamics of motion of the South American plate, J. Geophys. Res., this issue.

Mercier, J. L., D. Sorel, and K. Simeakis, Changes in the state of stress in the overriding plate of a subduction zone: The Aegean arc from the Pliocene to the present, Ann. Tecton., 1, 20-39, $1987 a$.

Mercier, J. L., R. Armijo, P. Tapponier, E. Carey-Gailhardis, and T. L. Han, Change from late Tertiary compression to Quaternary extension in southern Tibet during the India-Asia collision, Tectonics, 6, 275-304, $1987 \mathrm{~b}$.

Mercier, J. L., M. Sebrier, A. Lavenu, J. Cabrera, O. Bellier, J.-F. Dumont, and J. Machare, Changes in the tectonic regime above a subduction zone of Andean type: The Andes of Peru and Bolivia during the Pliocene-Pleistocene, J. Geophys. Res., this issue.

Michael, A. J., The use of focal mechanisms to determine stress: A control study, J. Geophys. Res., 92, 357-368, 1987.

Minster, J. B., and T. H. Jordan, Present-day plate motions, $J$. Geophys. Res., 83, 5331-5354, 1978.

Mitchell, B. J., O. W. Nuttli, R. B. Herrmann, and W. Stauder, Seismotectonics of the central United States, in The Geology of North America, Decade Map vol. 1, Neotectonics of North America, edited by B. Slemmons et al., pp. 245-260, Geological Society of America, Boulder, Colo., 1991.

Molnar, P., and Q. Deng, Faulting associated with large earthquakes and the average rate of deformation in central and eastern Asia, $J$. Geophys. Res., 89, 6203-6228, 1984.

Molnar, P., and P. Tapponnier, Cenozoic tectonics of Asia: Effects of a continental collision, Science, 189, 419-426, 1975.

Molnar, P., and P. Tapponnier, Active tectonics of Tibet, $J$. Geophys. Res., 83, 5361-5375, 1978.

Mooney, W. D., M. C. Andrews, A. Ginzburg, D. A. Peters, and R. M. Hamilton, Crustal structure of the northern Mississippi Embayment and a comparison with other continental rift zones, Tectonophysics, 94, 327-348, 1983.

Mount, V. S., and J. Suppe, State of stress near the San Andreas fault: Implications for wrench tectonics, Geology, 15, 1143-1146, 1987.

Mount, V. S., and J. Suppe, Present-day stress orientations adjacent to active strike-slip faults: California and Sumatra, J. Geophys. Res., this issue.

Müller, B., M. L. Zoback, K. Fuchs, L. Mastin, S. Gregerson, N. 
Pavoni, O. Stephansson, and C. Lunggren, Regional patterns of stress in Europe, J. Geophys. Res., this issue.

Nakamura, K., Volcanoes as possible indicators of tectonic stress orientation-Principle and proposal, J. Volcanol. Geotherm. Res., 2, 1-16, 1977.

Nakamura, K., K.H. Jacob, and J. N. Davies, Volcanoes as possible indicators of tectonic stress orientation-Aleutians and Alaska, Pure Appl. Geophys., 115, 87-112, 1978.

Nunn, J. A., and J. R. Aires, Gravity anomalies and flexure of the lithosphere at the Middle Amazon Basin, Brazil, J. Geophys. Res., 93, 415-428, 1988.

Okal, E. A., J. Talandier, K. A. Sverdrup, and T. H. Jordan, Seismicity and tectonic stress in the south central Pacific, $J$. Geophys. Res., 85, 6479-6495, 1980.

Parsons, B., and F. M. Richter, A relation between the driving force and the geoid anomaly associated with mid-oceanic ridges, Earth Planet. Sci. Lett., 51, 445-450, 1980.

Pavoni, N., Faltung durch Horizontalverschiebung, Eclogae Geol. Helv., 54, 515-534, 1961.

Petroy, D. E., and D. A. Wiens, Historical seismicity and implications for diffuse plate convergence in the Northeast Indian Ocean, J. Geophys. Res., 94, 12,301-12,319, 1989.

Plumb, R. A., and S. H. Hickman, Stress-induced borehole elongation: A comparison between the four-arm dipmeter and the borehole televiewer in the Auburn geothermal well, J. Geophys. Res., 90, 5513-5521, 1985.

Raleigh, C. B., J. H. Healy, and J. D. Bredehoeft, Faulting and crustal stress at Rangely, Colorado, in Flow and Fracture of Rocks, Geophys. Monogr. Ser., vol. 16, edited by H. C. Heard et al., pp. 275-284, AGU, Washington, D. C., 1972.

Rebai, S., H. Philip, and A. Taboada, Modern tectonic stress field in the Mediterranean region: Evidences for stress deviations at different scales, Geophys. J., in press, 1992.

Richardson, R. M., Ridge forces, absolute plate motions, and the intraplate stress field, J. Geophys. Res., this issue.

Richardson, R. M., and B. L. Cox, Evolution of oceanic lithosphere: A driving force study of the Nazca plate, J. Geophys. Res., 89, 10,043-10,052, 1984.

Richardson, R. M., and L. Reding, North American plate dynamics, J. Geophys. Res., 96, 12,201-12,223, 1991.

Richardson, R. M., and M. L. Zoback, Amazonas rift: Modeling stress around a Paleozoic rift in South America, Eos Trans. AGU, $71,1606,1990$

Richardson, R. M., S. C. Solomon, and N. H. Sleep, Tectonic stress in the plates, Rev. Geophys., 17, 981-1019, 1979.

Rivera, L., and A. Cisternas, Stress tensor and fault plane solutions for a population of earthquakes, Bull. Seismol. Soc. Am., 80, $600-614,1990$

Sbar, M. L., and L. R. Sykes, Contemporary compressive stress and seismicity in eastern North America: An example of intraplate tectonics, Geol. Soc. Am. Bull., 84, 1861-1882, 1973.

Shamir, G., M. D. Zoback, and C. B. Barton, In situ stress orientation near the San Andreas fault: Preliminary results to 2.1 km depth from the Cajon Pass scientific drillhole, Geophys. Res. Lett., 15, 989-992, 1988.

Sibson, R. H., Frictional constraints on thrust, wrench and normal faults, Nature, 249, 542-544, 1974.

Sipkin, S. A., Estimation of earthquake source parameters by the inversion of waveform data: Global seismicity, 1981-1983, Bull. Seismol. Soc. Am., 76, 1515-1541, 1986.

Sonder, L. J., Effects of density contrasts on the orientation of stresses in the lithosphere: Relation to principal stress directions in the Transverse ranges, California, Tectonics, 9, 761-771, 1990.

Stefanick, M., and D. M. Jurdy, Stress observations and driving forces models for the South American plate, J. Geophys. Res., this issue.

Stein, C. A., S. Cloetingh, and R. Wortel, Seasat-derived gravity constraints on stress and deformation in the northeastern Indian Ocean, Geophys. Res. Lett., 16, 823-826, 1989.

Stein, S., S. Cloetingh, D. A. Wiens, and R. Wortel, Why does near ridge extensional seismicity occur primarily in the Indian Ocean?, Earth Planet. Sci. Lett, 82, 107-113, 1987.

Stein, S., S. Cloetingh, N. H. Sleep, and R. Wortel, Passive margin earthquakes, stresses and rheology, in Earthquakes at NorthAtlantic Passive Margins: Neotectonics and Postglacial Re- bound, NATO ASI Ser. C, edited by S. Gregersen and P. Basham, pp. 231-259, Kluwer Academic, Boston, Mass., 1989.

Stephansson, O., L.-O. Dahlstrom, K. Berstrome, P. Sarkka, A. Vaatainen, A. Myrvang, O. Fjeld, and T. H. Hansen, Fennoscandian rock stress data base-FRSDB, Res. Rep. LULEA 1987:06, 120 pp., Lulea Univ., Lulea, Sweden, 1987.

Suleiman, A. S., D. R. Yarwood, and D. I. Doser, The source parameters of earthquakes along the passive margin of western Africa, Eos Trans. AGU, 70, 1219, 1989.

Suter, M., State of stress and active deformation in Mexico and western Central America, in The Geology of North America, Decade Map vol. 1, Neotectonics in North America, edited by B. Slemmons et al., pp. 401-422, Geological Society of America, Boulder, Colo., 1991.

Tapponnier, P., and P. Molnar, Slip-line field theory and large scale continental tectonics, Nature, 294, 319-324, 1976.

Thompson, G. A., and M. L. Zoback, Regional geophysics of the Colorado Plateau, Tectonophysics, 61, 149-181, 1979.

Turcotte, D. L., J. L. Ahern, and J. M. Bird, The state of stress at continental margins, Tectonophysics, 42, 1-28, 1977.

Vilotte, J. P., M. Daignieres, R. Madariaga, and O. C. Zienkiewicz, The role of a heterogeneous inclusion during continental collision, Phys. Earth Planet. Inter., 36, 236-259, 1984.

Vilotte, J. P., M. Daignieres, R. Madariaga, and O. C. Zienkiewicz, Numerical study of continental collision: Influence of buoyancy forces and a stiff inclusion, Geophys. J. R. Astron. Soc., 84, 279-310, 1986

Walcott, R. I., Gravity, flexure and the growth of sedimentary basins at a continental edge, Geol. Soc. Am. Bull., 83, 1845-1848, 1972.

Whittaker, A., M. H. P. Bott, and G. D. Waghorn, Stresses and plate boundary forces associated with subduction plate margins, J. Geophys. Res., this issue.

Wiens, D. A., and S. Stein, Intraplate seismicity and stresses in young oceanic lithosphere, $J$. Geophys. Res., 89, 11,442-11,464, 1984.

Wiens, D. A., and S. Stein, Implications of oceanic intraplate seismicity for plate stresses, driving forces, and rheology, Tectonophysics, 116, 143-162, 1985.

Wong, I. G., and J. R. Humphrey, Contemporary seismicity, faulting, and the state of stress in the Colorado Plateau, Geol. Soc. Am. Bull., 101, 1127-1146, 1989.

Wortel, M. J. R., and S. A. P. L. Cloetingh, Accretion and lateral variations in tectonic structure along the Peru-Chile Trench, Tectonophysics, 112, 443-462, 1985.

Wortel, M. J. R., M. J. N. Remkes, R. Govers, S. A. P. L. Cloetingh, and $P$. Th. Meijer, Dynamics of the lithosphere and the intraplate stress field, Philos. Trans. R. Soc. London, Ser. A, 337, $111-126,1991$

Xu, Z., S. Wang, Y. Huang, and A. Gao, Tectonic stress field of Chinese mainland inferred from a large number of small earthquakes, J. Geophys. Res., this issue.

Yang, J.-P., and Y. P. Aggarwal, Seismotectonics of northeastern United States and adjacent Canada, J. Geophys. Res., 86, 49814998, 1981.

Zoback, M. D., State of stress and crustal deformation along weak transform faults, Philos. Trans. R. Soc. London, Ser. A, 337, 141-150, 1991.

Zoback, M. D., and B. C. Haimson (Eds.), Hydraulic Fracturing Stress Measurements, 270 pp., U.S. National Committee for Rock Mechanics, National Academy Press, Washington, D. C. 1983.

Zoback, M. D., and J. H. Healy, Friction, faulting and in situ stress, Ann. Geophys., 2, 689-698, 1984.

Zoback, M. D., and M. L. Zoback, State of stress and intraplate earthquakes in the central and eastern United States, Science, $213,96-104,1981$

Zoback, M. D., and M. L. Zoback, Tectonic stress field of North America and relative plate motions, in The Geology of North America, Decade Map vol. 1, Neotectonics of North America, edited by B. Slemmons et al., pp. 339-366, Boulder, Colo., 1991.

Zoback, M. D., D. Moos, L. Mastin, and R. N. Anderson, Wellbore breakouts and in situ stress, J. Geophys. Res., 90, 5523-5530, 1985.

Zoback, M. D., et al., New evidence on the state of stress of the San Andreas fault system, Science, 238, 1105-1111, 1987. 
Zoback, M. L., State of stress and modern deformation of the northern Basin and Range province, J. Geophys. Res., 94, 71057128, 1989.

Zoback, M. L., Stress field constraints on intraplate seismicity in eastern North America, J. Geophys. Res., this issue.

Zoback, M. L., and M. Magee, Stress magnitudes in the crust: Constraints from stress orientation and relative magnitude data, Philos. Trans. Royal Soc. London, Ser. A, 337, 181-194, 1991.

Zoback, M. L., and M. D. Zoback, State of stress of the conterminous United States, J. Geophys. Res., 85, 6113-6156, 1980.

Zoback, M. L., and M. D. Zoback, Tectonic stress field of the conterminous United States, Mem. Geol. Soc. Am., I72, 523-539, 1989.
Zoback, M. L., S. P. Nishenko, R. M. Richardson, H. S. Hasegawa, and M. D. Zoback, Mid-plate stress, deformation, and seismicity, in The Geology of North America, vol. M, The Western North Atlantic Region, edited by P. R. Vogt and B. E. Tucholke, pp. 297-312, Geological Society of America, Boulder, Colo., 1986.

Zoback, M. L., et al., Global patterns of tectonic stress, Nature, $341,291-298,1989$.

M. L. Zoback, U. S. Geological Survey, 345 Middlefield Road, MS 977, Menlo Park, CA 94025.

(Received June 3, 1991;

accepted August 5, 1991.) 